\title{
Incontestability and Rights in Descriptive Trademarks
}

\author{
Suman Naresh $\dagger$
}

In Park 'N Fly, Inc. v. Dollar Park and Fly, Inc., ${ }^{1}$ the Supreme Court for the first time decided a substantive issue ${ }^{2}$ under the Lanham Act. ${ }^{3}$ The decision brought some welcome clarity to the incontestability provisions, which constitute one of the principal innovations of the Act. Although the Act has been with us for four decades, the implications of incontestability for trademark ${ }^{4}$ doctrine, and for competitive behavior in the marketplace, remain largely unexplored. Courts and commentators alike have chosen to treat the issues as narrow questions of statutory interpretation, with little attention to wider normative questions. ${ }^{5}$

$\dagger$ Associate Professor of Law, Tulane University. I am grateful to Edmund Kitch, Douglas Baird, Richard Epstein, and Cynthia Samuel for their criticisms of an earlier version of this article, and to my colleagues Catherine Hancock and Lloyd Bonfield for their support while it was being written; the errors that undoubtedly remain are mine alone. I wish also to acknowledge the research assistance of the following students at Tulane Law School: Jeanne Carriere and Paul Mutty, class of 1986, and Cornelia Henderson, class of 1987.

105 S. Ct. 658 (1985).

3 In Inwood Laboratories, Inc. v. Ives Laboratories, Inc., 456 U.S. 844 (1982), the majority opinion ignored the contributory infringement issue. It dealt only with the application of the "clearly erroneous" standard of Fed. R. Civ. P. 52(a). However, Justices White and Marshall, in concurrence, did discuss the substantive issue of palming off. Id. at 859 (White, J., concurring).

s Act of July 5, 1946, 60 Stat. 427 (codified at 15 U.S.C. $\$ \$ 1051-1127$ (1985)).

" In this article, the words "trademark" and "mark" mean any trade symbol that is legally protectable, whether under the Act or at common law, and whether entitled to registration under the Act or not. They therefore include, but are not limited to, a "trademark," a "service mark," and a "mark" as defined in the Act. A "trademark" is defined in the Act to include "any word, name, symbol, or device or any combination thereof adopted and used by a manufacturer or merchant to identify his goods, including a unique product, and distinguish them from those manufactured or sold by others and to indicate the source of the goods, even if that source is unknown." 15 U.S.C. $\$ 1127$ (1985). A "mark" is defined to include "any trademark, service mark, collective mark, or certification mark entitled to registration . . . whether registered or not," and a "service mark" to be "a mark used in the sale or advertising of services to identify and distinguish the services of one person, including a unique service, from the services of others and to indicate the source of the services, even if that source is unknown." Id.

3 See, e.g., Union Carbide Corp. v. Ever-Ready Inc., 531 F.2d 366 (7th Cir.), cert. denied, 429 U.S. 830 (1976); Fletcher, Incontestability and Constructive Notice: A Quarter Century of Adjudication, 63 TRADE-MaRK REP. 71 (1973); McKnight, §33(b) of the Lanham 
This article attempts to supply this deficiency in two ways: by explaining and evaluating incontestability. To this end, Part I discusses the common law of trademarks and states one of its most basic features: that a nondistinctive trademark may not be monopolized $^{6}$ and that the right to challenge a mark's distinctiveness cannot be lost by the mere passage of time. It explains how this rule reflects the courts' belief that descriptive trademarks provide valuable information to buyers and how competition would suffer if a seller, through a trademark monopoly, could hinder others from conveying information descriptive of their products.

Part II demonstrates how the Lanham Act's provisions on incontestability alter the common law. As the Supreme Court acknowledged in Park ' $N F l y$, the Act permits a seller to establish an exclusive right to use a nondistinctive mark, provided it is registered and sufficient time has elapsed. ${ }^{7}$ In an effort to determine the extent to which the Act changes the common law, the mechanics of incontestability are set out and its various exceptions explored. Finally, Part III evaluates the common law and statutory positions, and argues that granting incontestable rights in nondistinctive marks that are descriptive is anticompetitive and unnecessary for protecting the legitimate interests of trademark owners. It therefore concludes that the scope of incontestability should be narrowed in relation to such marks.

An essential requirement of the discussion that follows is terminological clarity: this part of trademark law is plagued by confusion in the use of terms, ${ }^{8}$ to which the drafters of the Lanham Act

Act: What Effect in Trade-mark Infringement Litigation?, 72 TRADE-MARK REP. 329 (1982); Comment, Incontestable Trademark Rights and Equitable Defenses in Infringement Litigation, 66 Mins. L. REv. 1067 (1982).

- It has been pointed out that the use of words like "monopoly," "property rights," and "ownership" in connection with trademarks frequently involves a "semantic misapplication" which reveals a bias against the legal protection of trademarks. $1 \mathrm{~J}$. Thomas McCarthy, Trademarks and Unfair Competition $\$ \S 2: 5,2: 6$, at 57-59, 66-68 (2d ed. 1984). In this article, however, these terms are used neutrally, as indicating simply that the legal system creates and enforces certain exclusive rights to the use of trade symbols. The existence of these exclusive rights may or may not be associated with the existence of monopolistic conditions in any relevant product market. For the meaning and the scope of "exclusive rights" in trademark law, see infra notes $63,101$.

${ }^{7}$ Park 'N Fly, $105 \mathrm{~S}$. Ct. at 667 . This holds provided that the nondistinctive mark in question is "descriptive" rather than "generic." See infra note 114 and accompanying text. The distinction between generic and descriptive marks is explained infra note 15.

8 Particularly troublesome is the possible confusion between the incontestability of substantive rights to use a trademark and the freedom from possible cancellation of its registration. The two ideas are in fact both conceptually and statutorily distinct, and the failure to distinguish between them has contributed to some restrictive interpretations of the incontestability doctrine. See infra notes $93-103$ and accompanying text. 
contributed by using the word "incontestable" twice but failing to define it. In this article, certain important terms are used only in specified ways. The phrase "incontestability provisions" refers to sections 14(c), 15, and 33(b) of the Lanham Act;"; "incontestable" and "incontestability" refer to the unchallengeability of substantive rights to use a trademark;" and "noncancellable" and "noncancellability" mean the unchallengeability of a trademark's registration.

\section{Trademarks at Common Law}

The common law of trademarks asserts that property rights can exist only in a "distinctive" mark ${ }^{12}$-one having an associative significance in the minds of buyers whereby they understand that all goods bearing it are connected in some way with a single source. ${ }^{13}$ It is irrelevant whether the mark is registered or unregistered $^{14}$ and whether it is claimed to have been distinctive from the outset or is an originally nondistinctive mark which through use has arguably become distinctive by acquiring "secondary meaning." 15 The right to monopolize a trademark can always be chal-

- See Lanham Act, $\S 15,16,15$ U.S.C. $\S \S 1065,1066$ (1985).

1015 U.S.C. $\S \S 1064$ (c), 1065, and 1115(b) (1985), respectively.

"I "Incontestability" is thus a product of 15 U.S.C. $\$ \$ 1065$ and 1115(b) (1985). While the latter section does not use the term, it refers to registration functioning as "conclusive evidence" of certain substantive rights. See infra notes 93-103 and accompanying text.

12 See, e.g., Armstrong Paint \& Varnish Works v. Nu-Enamel Corp., 305 U.S. 315, 33536 (1938); Kellogg Co. v. National Biscuit Co., 305 U.S. 111, 118-19 (1938); Canal Co. v. Clark, 80 U.S. 311, 322-23 (1872).

1s See Carter-Wallace, Inc. v. Procter \& Gamble Co., 434 F.2d 794, 802 (9th Cir. 1970); G.\&C. Merriam Co. v. Saalfield, 198 F. 369, 373 (6th Cir. 1912). The single source in question may be an anonymous one. See Fleischmann Distilling Corp. v. Maier Brewing Co., 314 F.2d 149, 155 (9th Cir.), cert. denied, 374 U.S. 830 (1963). There is no difference between "distinctiveness" and "secondary meaning." Park 'N Fly, 105 S. Ct. at 662.

14 Substantive trademark rights, even in relation to a registered mark, have their source in the common law. See infra note 69 and accompanying text. Because of this, the Act provides that a descriptive mark cannot be registered unless it "has become distinctive of the applicant's goods in commerce," Lanham Act $\S 2(e)$, (f), 15 U.S.C. $\S 1052(e)$, (f) (1985), and that its registration can be cancelled within the first five years upon proof of its nondistinctiveness. Lanham Act $\S$ 14(c), 37, 15 U.S.C. $\S \S 1064(c), 1119$ (1985). See infra notes $68,85-92$ and accompanying text.

${ }^{13}$ Trademark rights exist in a mark that is currently distinctive (or has secondary meaning). See supra note 12 (citing cases). In order to decide whether this is so, it is customary to begin by placing the mark in one of four categories: generic, descriptive, suggestive, and fanciful or arbitrary. See Zatarains, Inc. v. Oak Grove Smokehouse, Inc., 698 F.2d 786, 790-91 (5th Cir. 1983). In relation to the goods to which it is applied, a mark is generic if it is the name of the genus or class to which the goods belong; descriptive if it identifies some characteristic or quality of those goods, such as color, odor, function, mode of use, ingredients, etc.; suggestive if it suggests the characteristic or quality instead of describing 
lenged at common law on the ground that the mark is nondistinctive, irrespective of how long it has been used. ${ }^{16}$ Until Park ' $N$ Fly, all attempts to qualify these propositions had met with little success. ${ }^{17}$

No systematic evaluation of incontestability is possible until the foundations of this common law "distinctiveness criterion," which incontestability drastically alters, have been critically examined. Such an examination has seldom been undertaken, ${ }^{18}$ in part because the rule itself has never been seriously challenged. ${ }^{19} \mathrm{It}$ has sometimes been explained on the ground that descriptive

it, requiring the buyer to exercise some imagination in order to understand the nature of the goods; and fanciful or arbitrary if it is a coined word, or part of the ordinary language, respectively, and in either case bears no relationship to the goods involved. Id. The purpose of this classification is to decide whether proof of secondary meaning is required: such proof is unnecessary if the mark is classified as fanciful, arbitrary, or suggestive, since such marks are presumed irrebuttably to be "inherently distinctive" and therefore automatically protectable; proof is necessary if the mark is initially classified as descriptive and therefore protectable only upon such proof; and proof is irrelevant if the mark is classified as generic, since generic marks are unprotectable even if they have acquired "de facto" secondary meaning. Id.; see $1 \mathrm{~J}$. ThомAs McCaRTHY, supra note 6, §§ 12:15, 15:1, at 562-65, 656-57. Property rights can therefore exist only in a mark that is either inherently distinctive or was initially nondistinctive (though not generic) but acquired secondary meaning. In the Act, a generic mark is referred to as the "common descriptive name of an article or substance." Lanham Act, §§ 14(c), 15(4), 15 U.S.C. §§ 1064(c), 1065(4) (1985).

${ }^{18}$ See Kellogg Co. v. National Biscuit Co., 305 U.S. 111, 119 (1938). The possible challenges to the distinctiveness of a registered mark are discussed infra at note 114 and accompanying text.

17 Attempts at qualification have usually taken the form of protecting a mark that is currently descriptive. Thus, it is sometimes argued that "incipient secondary meaning" should be recognized, and a mark should be protected if its user is trying to make it distinctive but has not yet succeeded. See Handler \& Pickett, Trade Marks and Trade Names: An Analysis and Synthesis (part II), 30 CoLUM. L. REv. 759 (1930). This "doctrine" has been criticized as unclear and unnecessary, and has never actually been applied. See Scagnelli, Dawn of a New Doctrine: Trademark Protection for Incipient Secondary Meaning, 71 Trade-Mark Rep. 527 (1981). It was criticized in Perfect Fit Industries, Inc. v. Acme Quilting Co., 484 F. Supp. 643 (S.D.N.Y. 1979), which the Second Circuit chose not to review. See 618 F.2d 950 (2d Cir. 1980). It was decisively rejected by the Eighth Circuit in Black \& Decker Mfg. Co. v. Ever-Ready Appliance Mfg. Co., 684 F.2d 546 (8th Cir. 1982).

18 Notable exceptions are Folsom \& Teply, Trademarked Generic Words, 89 YALE L. J. 1323 (1980); Stern \& Hoffman, Public Injury and the Public Interest: Secondary Meaning in the Law of Unfair Competition, 110 U. PA. L. REv. 935 (1962). The former article, which deals with the narrower problem of the monopolization of generic terms, does not amount to such an examination, for it does not explain why distinctiveness is required even for descriptive terms that are not generic. It therefore fails to provide a basis for the evaluation of incontestability, for the very change brought about by this doctrine is that it permits the monopolization of such terms. See supra note 7 and accompanying text. In relation to its specific purpose, however, it makes use of the economic analysis of information, which is the basis of the argument developed in the present article. See infra notes 35-59 and accompanying text.

10 Such challenges as have been made, and their general lack of success, are discussed supra note 17 . 
marks are part of the common stock of language, and so belong irrevocably in the public domain. ${ }^{20}$ But this is a conclusion, not a reason, and in any event fails to explain why in some circumstances ordinary language may unquestionably be so withdrawn. ${ }^{21}$ More cogently, it has been argued that descriptive marks are placed in the public domain to keep them freely available for use by all producers of the goods that they describe. ${ }^{22}$ This is undoubtedly true, but does not explain why they must always remain in the public domain, even when the interests of competitors in being able to use descriptive marks has arguably been overborne by the countervailing interests of long-standing users in continuing to have exclusive use of them. Therefore, a proper appreciation of the common law rule requires the identification of the nature of a competitor's interest in using a descriptive mark and an assessment of its strength; both of these depend, it is suggested, upon the informative role of trademarks.

\section{A. Trademarks as Information}

1. Information $v$. Persuasion. Trademarks convey information about the goods to which they are applied-their characteristics, ${ }^{23}$ for example, or their source ${ }^{24}$-with the object of causing consumers to increase their purchases of those goods. This widely accepted proposition is regarded as so obvious as to be uninteresting, so that the nature and extent of the information conveyed are rarely investigated. Attention tends instead to focus upon trademarks' more controversial role, that of persuasion, ${ }^{25}$

20 See, e.g., Charcoal Steak House of Charlotte, Inc. v. Staley, 263 N.C. 199, 201, 139 S.E.2d 185, 187 (1964); Farm Serv., Inc. v. United States Steel Corp., 90 Idaho 570, 589, 414 P.2d 898, 908 (1966) (featuring photographs of pickup trucks and billboards bearing the words in question).

21 For example, when it acquires distinctiveness. See supra note 15 and accompanying text.

${ }^{22}$ See Estate of P.D. Beckwith, Inc. v. Commissioner of Patents, 252 U.S. 538, 543-44 (1920).

23 See Roux Laboratories, Inc. v. Clairol, Inc., 427 F.2d 823, 826 (C.C.P.A. 1970) (concerning the slogan "Hair Color So Natural Only Her Hairdresser Knows For Sure").

24 A mark that provides information about source is said to be "distinctive," and is the only kind of mark that can be protected at common law. See supra notes 12-13 and accompanying text. The nature of information about source, and the fact that it is an indirect way of providing information about product characteristics is explained infra at notes $35^{\circ} 44$ and accompanying text.

${ }^{28}$ It is true that the informative role of trademarks has frequently been lauded and made the basis of pleas for enhanced trademark protection. See Pattishall, Trade-Marks and the Monopoly Phobia, 50 Mrch. L. Rev. 967, 979 (1952); Rogers, The Lanham Act and the Social Functions of Trade-Marks, 14 Law \& ConTemp. Prons. 173, 176-77, 180 (1949). 
which they are said to perform by encapsulating advertising messages which alter consumers' tastes and cause them to buy more of the advertised goods. ${ }^{26}$ It tends then to be urged that trademark law should be comprehensively reoriented, either to recognize explicitly the persuasive function's legitimacy and so enhance the legal protection of trademarks, ${ }^{27}$ or to narrow the protection on the ground that persuasion undesirably strengthens irrational brand preferences and gives trademark owners monopoly power. ${ }^{28}$ These arguments as to appropriate trademark policy, although rooted in economic theories that developed a half-century or more ago, continue unabated to this day, making their influence felt in academic circles and judicial opinions alike. ${ }^{2 \theta}$

This article takes no position on either the reality or the legitimacy of the persuasive function. The reason for this neutrality is that, since virtually nothing is known about how consumers' tastes are formed, ${ }^{30}$ it is impossible to determine whether an advertise-

But most of the academic discussion has centered upon the persuasive function. See Brown, Advertising and the Public Interest: Legal Protection of Trade Symbols, 57 Yale L.J. 1165, 1187 (1948); Schechter, The Rational Basis of Trademark Protection, 40 HARv. L. REv. 813, 822 (1927).

${ }^{28}$ See Brown, supra note 25; see also Mishawaka Rubber \& Woolen Mfg. Co. v. S.S. Kresge Co., 316 U.S. 203 (1942), which contains Justice Frankfurter's celebrated statement:

The protection of trade-marks is the law's recognition of the psychological function of symbols. If it is true that we live by symbols, it is no less true that we purchase goods by them. A trade-mark is a merchandising short-cut which induces a purchaser to select what he wants, or what he has been led to believe he wants. The owner of a mark exploits this human propensity by making every effort to impregnate the atmosphere of the market with the drawing power of a congenial symbol. Whatever the means employed, the aim is the same-to convey through the mark, in the minds of potential customers, the desirability of the commodity upon which it appears. Once this is attained, the trade-mark owner has something of value. If another poaches upon the commercial magnetism of the symbol he has created, the owner can obtain legal redress.

Id. at 205. For a recent and decidedly doom-laden account of the sinister, manipulative tendencies of advertising, see StUART EwEn, Captains of Consciousness 81-102 (1976).

${ }^{27}$ See Schechter, supra note 25, at 818-19.

${ }^{28}$ See Brown, supra note 25. Professor Brown draws upon the economic analysis of product differentiation in Edward Chamberdin, The Theory of Monopolistic Competition (8th ed. 1962). In Appendix E, Professor Chamberlin discusses the implications of his theory for trademark protection, concluding that less extensive protection would reduce the extent to which a seller with a strong trademark is insulated from competition. For a well-known judicial expression of this viewpoint, see Standard Brands, Inc. v. Smidler, 151 F.2d 34, 41 (2d Cir. 1945) (Frank, J., concurring).

29 See John Kenneth Galbraith, The New Industrial State 211-20 (3d ed. 1978); Smith v. Chanel, Inc. 402 F.2d 562, 567 (9th Cir. 1968).

so See Nelson, The Economic Consequences of Advertising, 48 J. Bus. 213, 213 (1975); Nelson, The Economic Value of Advertising, in Advertising AND Society 43, 44 (Y. Brozen ed. 1974). 
ment employing trademarks affects these tastes and, if so, the nature and direction of that effect. ${ }^{31}$ This impossibility thwarts any attempt to explain trademark use which incorporates the proposition that trademarks may persuade consumers (i.e., alter their tastes) instead of, or as well as, informing them: any aspect of behavior that is inexplicable under other elements in the theory is ascribed to the persuasive effects of trademarks. Since this ascription can neither be confirmed nor falsified, the explanation becomes a mere tautology. Concentration upon trademarks' informative role, on the other hand, avoids these difficulties and enables the formulation of a theory with genuine explanatory power, ${ }^{32}$ whose limits are more readily discernible. Attention will therefore be directed to a trademark's informational content, and to the methods by which this information is conveyed. Such an examination will reveal that the informational role of trademarks is more extensive and complex than is generally realized, and will shed light upon the special importance of descriptive marks.

2. Informative Capacity of Trademarks. It is easy to see, at least in part, how any trademark provides information: it often tells buyers about product characteristics, such as the category to which the goods belong, their function, their mode of operation or use, their ingredients or qualities, and their effects. ${ }^{33}$ Less obvious is the notion that the manner in which a trademark conveys information is also significant, and has an important bearing upon the content of the information. In order to understand this, it is necessary to consider the difference between the two possible modes of information transfer: direct and indirect. ${ }^{34}$

A trademark conveys information directly by virtue of its natural meaning or descriptiveness, and indirectly by enabling buyers to link the labeled goods with a stock of information associated with the mark as a result of how it has been used. To illustrate, while "Prego Plus Veal \& Mushroom" provides direct information about the ingredients of the spaghetti sauce to which it is applied, "Kodak" provides no direct information about the cameras on which it appears, for it is a coined word having no natural mean-

31 See Coase, Advertising and Free Speech, 6 J. LEGAL Stud. 1, 9-13 (1977).

32 See Nelson, The Economic Value of Advertising, supra note 30, at 44-46.

ss See supra note 15 (discussing generic and descriptive marks). Examples include the mark "Easy Load" for cassette tape recorders (In re Sony Corp., 176 U.S.P.Q. (BNA) 61 (T.T.A.B. 1972)), and the mark "Continuous Progress" for a packaged educational program (Educational Dev. Corp. v. Economy Co., 562 F.2d 26 (10th Cir. 1977)).

"A distinction similar to the one made in the text is made by Nelson, The Economic Value of Advertising, supra note 30, at 49-52. 
ing. "Kodak" does, however, provide a considerable body of indirect information: many buyers have learned, through consumption or otherwise, to associate "Kodak" with certain quality and performance characteristics of cameras, and they link this body of knowledge with all cameras bearing that mark. ${ }^{35}$

In general, the direct information conveyed by a trademark is relatively precise, while the indirect information, being inferential, is relatively indefinite. But this might not be so, for the mark's natural meaning may convey no more than the barest suggestion ${ }^{36}$ about the characteristics of the trademarked goods (as with the mark "Caress" for soap or "Enhance" for shampoo), and a coined mark may be associated with a body of information specific enough to support definite inferences. For example, buyers to whom "Kodak" signifies cameras having certain well-defined characteristics and coming from one manufacturing source ${ }^{37}$ can confidently make relatively detailed predictions about some of the features of any camera bearing that mark. If this body of associated information were to become less specific, however (as it would if "Kodak" were also associated with products unrelated to photography), or if buyers could no longer legitimately make confident inferences from it (as would be the case if "Kodak," though employed only on cameras, were used by many manufacturers), the quality of the indirect information provided by the mark would deteriorate. ${ }^{38}$

The direct and indirect modes of conveying product information are not mutually exclusive: a highly descriptive mark can become so associated with a particular product from a particular source that it will begin conveying indirect as well as direct information to buyers. ${ }^{39}$ The converse is less likely, for an invented

ss One camera bearing the mark "Kodak," for instance, can be expected to be virtually identical with every other camera (of the same model) with that mark, and at least substantially similar to Kodak cameras of different models.

${ }^{30}$ This may cause such a mark to be classified as "suggestive," rather than "descriptive." See supra note 15 (discussing these categories).

${ }^{37}$ See supra note 13 and accompanying text.

s8 Thus, each of the two kinds of information conveyed by a trademark may vary in its specificity from very precise to very imprecise.

30 The two kinds of information may be conveyed to different groups of buyers, so that some may associate the mark only with a source and others may treat it as only descriptive. To some buyers the mark may have both meanings, and they may constitute a small or large proportion of the total purchasing "universe." See Anti-Monopoly, Inc. v. General Mills Fun Group, Inc., 684 F.2d 1316, 1321 (9th Cir. 1982); Bayer Co. v. United Drug Co., 272 F. 505, 510 (S.D.N.Y. 1921). The situation in which the two kinds of information are conveyed to distinct groups of buyers has been termed "discontinuous hybridness," and that in which both kinds are conveyed to the same group of buyers has been termed "simultaneous hybridness." See Folsom \& Teply, supra note 18, at 1339-40. See generally Swann, The 
word has no natural meaning; yet even a coined word, as a result of how the public uses it, may occasionally be absorbed into the ordinary language and acquire a "natural" meaning that it originally lacked-a process of which the word "aspirin" provides a celebrated example. ${ }^{40}$ Notwithstanding these possibilities, however, a particular mark's capacities to convey direct and indirect information are inversely related to each other. The greater a mark's natural descriptiveness, the less likely it is that buyers will be able to associate it with only a small range of products coming from a single source, and consequently with a precise body of information from which strong inferences can be drawn, and vice versa. ${ }^{41}$ It is true that a seller can influence these capacities in some degree. For example, it can enhance a highly descriptive mark's capacity to convey indirect information by adding a distinguishing feature to $i^{42}$ or by procuring a legal restriction upon the rights of others to use it. ${ }^{43}$ But these techniques have limited scope, especially in relation to coined marks, whose acquisition of "natural" meaning, and thus of a capacity to convey direct information, depends primarily upon public use. ${ }^{44}$ In large measure, therefore, the informative capacities of marks must be treated as a given.

The analysis presented above of the informative role of trademarks permits a clearer understanding of the concepts of "distinctiveness" and "secondary meaning," and makes possible a restatement of the common law distinctiveness criterion. Conventionally, a mark is said to be distinctive if buyers make an association which leads them to believe that all goods bearing the mark are connected in a source-related way. It should now be apparent that this

Validity of Dual Functioning Trademarks: Consumerism Tested by Consumer Understanding Rather Than By Consumer Use, 69 Trade-Mark ReP. 357 (1979).

${ }^{10}$ When this happens, such a word becomes a generic term. See Bayer Co., 272 F. at 512; supra note 15 (discussing generic marks).

4 On the so-called "spectrum of distinctiveness," therefore, which extends from generic marks at one extreme to arbitrary or fanciful marks at the other, a mark's capacity to convey direct information decreases, and to convey indirect information increases, as it becomes more distinctive. See $1 \mathrm{~J}$. Thomas McCarthy, supra note $6, \S 11: 1$, at 433-34; supra note 15.

12 One example, in Park 'N Fly, is the respondent's use of the word "Dollar" as a distinguishing feature.

43 For example, incontestability, by permitting the acquisition of exclusive rights in a registered descriptive mark, enhances such a mark's capacity ultimately to become distinctive and so convey indirect information.

"This is the reason for regarding such a mark as fanciful or arbitrary, and treating it as "inherently distinctive," i.e., as having so high a capacity for becoming distinctive as to dispense with the need for proof of distinctiveness. See $1 \mathrm{~J}$. Thomas McCarTHy, supra note $6, \S 11: 2$, at $435-36$; supra note 15 . 
is the same as saying that the mark must be functioning in the marketplace to convey indirect information either exclusively or together with direct information; ${ }^{45}$ and that the distinctiveness criterion makes such functioning the essential condition of property rights in a trademark. No monopoly is possible of a mark that neither possessed a high capacity to convey indirect information at the outset, nor was used in such a way as to become an effective transmitter of such information, despite its limited potential in this respect.

3. A Theory of Trademark Choice. The preceding discussion of the informative capacity of trademarks was largely definitional, and shed no light on behavior concerning trademarks. It demonstrated how marks convey information, and the informational implications of choosing particular kinds of marks, but did not explain which marks sellers will choose or why. In this section, the process of trademark choice in the light of informational considerations will be explored in detail.

At the threshold of these considerations is cost. A mark's capacity to convey direct information can be realized quickly and cheaply, simply by exploiting its natural meaning; its capacity to convey information indirectly, on the other hand, cannot be realized until the seller invests time and resources in achieving buyer recognition. Even a highly distinctive mark with great inherent capacity for conveying indirect information, used only by one seller on one product, does not convey anything until, through use and advertisement, buyers have learned to associate it with that source and that product. ${ }^{48}$ Therefore, a seller who chooses a relatively descriptive mark can instantly convey a certain amount of (direct) information "free," whereas one who chooses a relatively distinctive mark starts with a smaller bonus and may ultimately incur considerable expense to convey some (indirect) information. This creates an incentive for sellers and advertisers to choose descriptive marks that has frequently been remarked, but perhaps inadequately understood. ${ }^{47}$

45 See supra note 39 and accompanying text.

46 Thus, it is sometimes said that even a fanciful, inherently distinctive mark does not acquire "strength" in the marketplace until it acquires customer recognition. $1 \mathrm{~J}$. THOMAS McCarthy, supra note 6, § 11:1, at 434.

47 See, e.g., Franklin Knitting Mills, Inc. v. Fashionit Sweater Mills, Inc., 297 F. 247, 248 (S.D.N.Y. 1923), aff'd, 4 F.2d 1018 (2d Cir. 1925). There are similar observations in Aloe Creme Laboratories, Inc. v. Milsan, Inc. 423 F.2d 845, 848 (5th Cir.), cert. denied, 398 U.S. 928 (1970); Procter \& Gamble Co. v. Johnson \& Johnson, Inc., 485 F. Supp. 1185, 1210-11 (S.D.N.Y. 1979). 
One might conclude from this that sellers always prefer descriptive marks to distinctive ones. But this is not so, for against the ease and lack of expense with which a descriptive mark conveys direct information must be balanced the difficulty and expense entailed in conveying indirect information. The way in which a particular seller will strike the balance, and therefore the kind of mark it will choose, will depend upon the relative values to it of conveying direct and indirect information.

a. The analysis of characteristics. The basic behavioral proposition underlying this analysis of mark choice is that sellers convey the information that buyers demand, ${ }^{48}$ and buyers demand the most reliable information available. ${ }^{10}$ Each product comprises a bundle of individual characteristics, and buyers seek the best information available about each characteristic. ${ }^{50}$ As to some characteristics, this may be direct, descriptive information, but as to others, buyers may judge such information unreliable and desire instead to be indirectly informed. For example, they may prefer to know that the product having the characteristic in question comes from a source they have learned to know and trust through a particular trademark. In general, buyers find direct information reliable only when they can independently verify its truth. Ease of verification varies greatly from one characteristic to another and depends, other things being equal, upon two factors: the type of characteristic and the specificity of the best information communicable about it.

Economists customarily classify product characteristics into three categories: "search," "experience," and "credence."51 A search characteristic is one (such as size, shape, or appearance) that buyers can inspect virtually costlessly before purchasing the product, so that verification of information concerning it is easy. At the other extreme, verification is almost impossible in the case

4s See Telser, Advertising and Competition, 72 J. PoL. Econ. 537, 551-54 (1964); Nelson, The Economic Value of Advertising, supra note 30, at 44.

4 See Nelson, The Economic Value of Advertising, supra note 30, at 48-50.

${ }^{\text {so }}$ For example, a candy bar may be viewed as a bundle of characteristics including size, shape, taste, nut content, and nutritional value; an automobile may be viewed as a bundle including size, appearance, comfort, power, gasoline consumption, and repair frequency. Each may, of course, have other characteristics as well. The technique of viewing a product as a bundle of characteristics derives from Lancaster, A New Approach to Consumer Theory, 74 J. PoL. Econ. 132, 133 (1966).

${ }^{81}$ This proposition, as well as the analysis in the rest of this section, relies heavily upon the influential analysis of advertising by Phillip Nelson. In addition to the two articles cited supra note 30, see Advertising as Information, 82 J. PoL. EcoN. 729 (1979); Information and Consumer Behavior, 78 J. PoL. EcoN. 311 (1970). 
of a credence characteristic, for independent information about such a characteristic (for example, the nutritional value of foods or the chemical composition of medication) is available only at prohibitive cost, if at all. ${ }^{62}$ Between these two extremes lie experience characteristics, about which buyers can obtain independent information only through actual consumption or use of the product. Verification in these cases depends upon the cost of making test purchases: it is easy for a characteristic such as the taste of most food products, but may be difficult for one such as the mechanical reliability of an expensive consumer durable good.

The hypothesis that buyers demand and sellers supply the most reliable information available implies that buyers seek direct information only when it is easily verifiable - that is, only when it relates to either search characteristics or to experience characteristics of inexpensive, frequently purchased goods. Conversely, buyers seek indirect information about credence characteristics and about experience characteristics of costly durable goods. These implications assume, however, that all else remains constant as the characteristic's category changes. They may not hold true once account is taken of the other variable influencing ease of verification: the specificity of the best information that can be conveyed.

The category to which a product characteristic belongs influences ease of verification because it affects buyers' opportunities to obtain independent information: such information is plentiful and inexpensive for search characteristics, scarce and costly for credence characteristics. Ease of verification requires, however, not only that independent information be readily available, but also that it be specific enough to permit reasonably unambiguous confirmation. If independent information about a characteristic is easily available, but at best only vague and unspecific, verification will be difficult and buyers will not demand direct information from sellers. A common example of this is the taste of food products. Buyers can obtain independent information about taste easily and at little cost, but the characteristic cannot be described objectively and particularly enough to permit buyers to confirm the truth of the seller's description. Because of this, buyers seldom seek and sellers seldom supply any direct information about taste; buyers prefer to be informed indirectly: by hearing, for example, that a particular product is popular, which implies that it tastes good..$^{63}$

${ }^{82}$ See Darby \& Karni, Free Competition and the Optimal Amount of Fraud, 16 J.L. \& Econ. 67, 68-72 (1973).

${ }^{83}$ See Nelson, The Economic Value of Advertising, supra note 30, at 49-50. 
In contrast, a closely related characteristic of food products-their ingredients-is capable of precise description. Direct information as to ingredients is therefore easily verifiable; so buyers wish to know, and sellers rush to tell them, whether the frozen pizza being sold has sausage or pepperoni, the spaghetti sauce has mushrooms, or the candy bar has nuts.

b. From characteristics to products. If products typically had only a limited range of characteristics, sellers could easily decide what information to convey: direct information for a cheap product comprising only search and experience characteristics capable of reasonably precise description, and indirect information for a product whose only characteristics were credence characteristics or unspecific experience characteristics. In fact, of course, most products have many different characteristics; typically, therefore, a seller will wish to convey both direct and indirect information. In many cases this presents no problem: the seller can convey direct information by some means other than a trademark, and is then free to choose a distinctive trademark, with a high inherent capacity to convey the indirect information desired. For example, a seller of shampoo conveys direct, verifiable information concerning many search and experience characteristics of its product simply by using the generic term "shampoo"; a seller of candy bars does the same for its product partly by using the generic term "chocolate," and partly by using conventional shapes and packaging. In both cases, the seller can then choose a distinctive mark which, in time, will provide indirect information to buyers about characteristics such as glamor or taste.

The more difficult cases are those in which the mix of desired information is such that the direct component cannot easily be conveyed by generic terms or packaging. Perhaps the product has no generic name (as with many new products, such as the specialized parking services in Park ' $N$ Fly, comprising parking close to an airport and prompt conveyance to and from the airport), or the generic name may be inadequate to convey the desired direct information ("shampoo" does not indicate the presence of any special ingredients, such as "balsam and protein"). Moreover, no other devices (such as shapes or packaging) may be generally understood as signifying the possession of certain characteristics (for instance, that the spaghetti sauce contains veal and mushrooms). In such cases, the seller can inform buyers by stating the characteristics 
separately from the trademark, ${ }^{54}$ or by using instructional advertisements or point-of-sale displays. Such techniques would keep the trademark itself distinctive but are generally unsatisfactory because they reach a smaller number of people, and their repeated use is both more expensive and less memorable than the use of advertisements featuring trademarks. ${ }^{55}$

As a result, sellers of certain products must choose between a distinctive mark, with its associated diminution in the volume, specificity, and memorability of the direct information conveyed, and a descriptive mark, which is ill-fitted to attain distinctiveness and effectively transmit indirect information. In making this choice, a rational seller will balance its interests in conveying the two kinds of information, and will adopt a descriptive mark only when the expected gain in its ability to convey direct information exceeds the expected loss in its ability to convey indirect information. This usually will occur only when, in its judgment, direct information is the more relevant to buyers' purchasing decisions: when the characteristics to which direct information relates are more important to these decisions than those to which indirect information relates. Information about the overall taste of a candy bar, for example, may reasonably be thought more relevant to the decision whether to purchase candy than information relating to its particular ingredients (such as coconut, caramel, or peanuts). In the case of shampoo, on the other hand, information on unusual ingredients may be thought more important to purchasing decisions than whether the shampoo produces a lustrous sheen. This may lead a rational seller to adopt a distinctive mark for the candy bar (with the particular ingredients appearing only in supplementary fine print), and a descriptive one for the shampoo (e.g., "Suave Balsam and Protein").

\section{B. Basis and Significance of the Common Law Distinctiveness Criterion}

1. The Prevention of Informational Barriers. The analysis of mark choice presented above makes it possible to identify the nature of a seller's interest in using a descriptive mark, and thus bet-

s4 For example, "PETER PAUL milk chocolate and coconut."

ss These are the techniques that the majority of the Supreme Court mentioned as possible substitutes for the use of trade names in Friedman v. Rogers, 440 U.S. 1, 16 (1979). See also Northam Warren Corp. v. Universal Cosmetic Co., 18 F.2d 774, 775 (7th Cir. 1927), in which Judge Page, in a lyrical opinion, opined that advertisements containing trademarks are far more memorable than those that do not. 
ter to understand the common-law rule against exclusive appropriation of such marks. The core of this analysis is that the choice of a mark is influenced by its informational implications. A seller will use a descriptive mark only when it seeks to convey a particular and important kind of information which cannot easily be conveyed by any other means. If there are many sellers of a product, all of whom wish to use a certain descriptive mark, allowing one of them to monopolize that mark would create an informational barrier between buyers and other sellers. The common law distinctiveness criterion embodies a perception that this informational barrier would be substantial and should not be permitted.

This perception is justifiable. It is familiar learning that to compete effectively under conditions of imperfect knowledge, a seller must not only offer a good substitute for its competitors' products, but also tell buyers that it has done so. ${ }^{56}$ Failure to convey information about the product is tantamount both to increasing its price, ${ }^{57}$ because buyers must pay to obtain this information elsewhere, and to lessening its attractiveness. The seller's resulting competitive disadvantage is directly proportional to the importance that buyers attach to the missing information, and to the difficulty they experience in obtaining it by some other means. A failure to communicate a candy bar's nutritional value, for example, is unlikely to cause a competitive disadvantage because buyers typically do not regard this as important information; in contrast, a failure to inform buyers about the special ingredients of a shampoo may significantly lessen its competitive attractiveness.

Monopolization of descriptive marks would create serious informational barriers by impeding the flow of direct information important to buyers' purchasing decisions. A seller will choose a descriptive mark, which cannot easily be made distinctive, only when it judges that the product characteristics that are most relevant to purchasing decisions are those for which direct, verifiable information is available and demanded: $:^{58}$ only then is it worthwhile choosing a mark with a low capacity for distinctiveness and for transmit-

ss See Stigler, The Economics of Information, 69 J. PoL. Econ. 213 (1961); see also Folsom \& Teply, supra note 18, at 1340-46 (offering an account of the informational barriers created by the monopolization of generic terms).

${ }^{67}$ See Benham, The Effect of Advertising on the Price of Eyeglasses, 15 J.L. \& EcoN. 337 (1972).

ss Thus, most of the brand names discussed in Proctor \& Gamble Co. v. Johnson \& Johnson Inc., 485 F. Supp. 1185 (S.D.N.Y. 1979), were descriptive ones, and were intended to be used in connection with products fitting this description. For examples, and for Judge Leval's comments on this, see $i d$. at $1210,1211$. 
ting indirect information. Preventing a seller from conveying the very information that buyers want most would put it at a serious competitive disadvantage as compared to the seller with a monopoly of the descriptive mark. The mark owner would be shielded from competition and thus be able to charge a higher price. ${ }^{50}$ Buyers would be less able to identify substitutes for the mark owner's goods, and would therefore purchase more from the mark owner and less from other sellers than if they had been more completely informed. There would not only be private competitive harms to individual sellers and buyers, but also social harm resulting from a misallocation of resources.

2. Possible Counter-Arguments. It may be urged that this analysis overstates the magnitude of the harms resulting from the monopolization of descriptive trademarks, because it ignores the possible ways in which buyers and competitors might surmount the informational barriers created. Arguably, buyers could obtain the desired direct information by inspecting the product before purchase or by making test purchases, and competitors could convey that information in a number of ways, some of which do not involve using the monopolized mark, while others do but in a way that lies outside the monopoly.

There is less to these possibilities, however, than meets the eye. It is true that the products about which buyers seek direct information are often inexpensive and frequently purchased, so that test purchases of them can easily be made. But such purchases would in fact be made only when the expected gain from experimentation exceeded its expected cost. ${ }^{60}$ In most cases, the expected gain would be low, because of the low price of the products involved; while the expected cost would be high, if the tested product lacked the desired characteristics. Buyers would therefore be unwilling to undertake investigations for (at best) small gains, and would prefer to continue buying the descriptive-mark owner's product.

The possibilities open to competitors would be similary negligible. It may seem that competitors, even if barred from using the monopolized mark, could convey the desired direct information in

so See Benham, supra note 57, at 344-45, discussing the effect upon the price of eyeglasses of the informational barrier created by restrictions upon advertising.

${ }^{60}$ The expected gain is the likely difference in price, discounted by the probability that the inspection or experiment will yield a negative determination. The cost of inspecting or experimenting will be high if the products are located quite far apart: for example, in the case of airport parking, a customer in a hurry will rarely be willing to spend the time necessary to look for alternatives. 
many different ways: by using generic terms or conventional shapes and packaging, by using descriptive marks other than the one monopolized, or by using the monopolized mark itself in ways that are sheltered by the doctrine of "fair use."61 On closer inspection, however, these possibilities turn out to be illusory. As was shown in the analysis of mark choice, if adequate generic terms or conventional indications were available, they would have been used in the first place, along with a distinctive mark. There would then have been no incentive to choose a descriptive mark, with its low capacity for conveying indirect information. Further, it is unlikely that many substitute descriptive (non-generic) marks would exist, for the marks that aptly describe the relevant characteristics would probably be few, ${ }^{62}$ and some of these would be unusable because of the risk that a court would find them "confusingly similar" to, and thus an infringement of, the monopolized mark. ${ }^{63}$ And finally, while the fair use doctrine permits a competitor to use the monopolized mark itself in certain ways, without fear of an infringement action, these ways do not include its "use as a trademark." They do not, therefore, include using the mark as an "attention-getting symbol,"6s whether alone or as the most prominent part of a composite containing other elements. ${ }^{68}$ Competitors would thus be forced to use the mark innocuously, making it impossible for them to convey direct information efficiently to large numbers of buyers.

The private and social harms resulting from the monopolization of descriptive marks would therefore be considerable, for the informational barrier to competitors would be significant and not easily surmountable. It is this possibility that the common law responds to by limiting the acquisition of property rights to marks

61 Lanham Act, § 33(b)(4), 15 U.S.C. § 1115(b)(4) (1985).

62 This is because the range of a mark's natural descriptiveness is limited.

os While the owner of a validly monopolized mark has no absolute monopoly of its use, the owner does have a right to prevent others from infringing by using that mark, or any other mark, in a manner likely to produce confusion as to the source of the respective goods. Motorola, Inc. v. Griffiths Elecs., Inc., 317 F.2d 397, 400 (C.C.P.A. 1963). This is true whether or not the mark is registered. New West Corp. v. N.Y.M. Co., 595 F.2d 1194, 1201 (9th Cir. 1979); Holiday Inns of America, Inc. v. B.\&B. Corp., 409 F.2d 614, 616 (3d Cir. 1969); Lanham Act, § 32(1), 15 U.S.C. § 1114(1) (1985).

- See supra note 61.

6s See Venetianaire Corp. of Am. v. A \& P Import Co., 429 F.2d 1079, 1082 (2d Cir. 1970); Louis Rich, Inc. v. Horace W. Longacre, Inc., 423 F. Supp. 1327, 1339 (E.D. Pa. 1976); Mobil Oil Corp. v. Mobile Mechanics, Inc., 192 U.S.P.Q. 744, 749 (D.C. Conn. 1976).

8 In Soweco Inc. v. Shell Oil Co., 617 F.2d 1178, 1187 (5th Cir. 1980), cert. denied, 450 U.S. 981 (1981), for example, the descriptive mark LARVACIDE was not a prominent part of the defendant's mark, and hence was fairly used. 
that always were, or have become, distinctive. ${ }^{67}$ Such marks function in the marketplace to convey indirect information about a particular seller's product, and there is no private or social interest in making them available for use by all.

\section{The Impact of the Lanham Act}

\section{A. The Park 'N Fly Decision}

The Lanham Act's incontestability provisions significantly alter the common-law distinctiveness criterion. Section 2(e) and (f) of the Act permit registration of a descriptive mark if the Patent and Trademark Office ("PTO") is satisfied that the mark has acquired distinctiveness. ${ }^{68}$ But registration by itself has no effect upon substantive rights: the validity of the registrant's claims of distinctiveness, and consequently its right to monopolize the registered mark, continues to be tested by common law standards. ${ }^{69}$ If a court, applying these standards, finds the mark lacking in distinctiveness, the registrant cannot exclude others from using it. ${ }^{70}$ When certain conditions have been satisfied, however, the incontestability provisions allow a registrant to obtain an unchallengeable monopoly of a nondistinctive mark. These conditions are routine and mechanical: notably, they neither require nor provide any occasion for any substantive consideration of the question whether the registered mark is distinctive ${ }^{71}$ or, if not, whether it is desirable

or See supra note 12 and accompanying text.

68 15 U.S.C. $\S 1052(\mathrm{e})$, (f) (1985). Under these provisions, a mark may be registered upon becoming distinctive, not only when it is merely descriptive of the goods, but also when it is deceptively misdescriptive of them, or primarily geographically descriptive or deceptively misdescriptive of them, or when it is primarily merely a surname. Because the problems raised by these other kinds of marks are closely analogous to those raised by merely descriptive marks, no separate reference is made to them in this article.

- Under the Act, registration is not the source of substantive rights: section 1 provides that the "owner of a trademark" may register it, implying that ownership itself is derived from the common law. 15 U.S.C. $\$ 1051$ (1985) (emphasis added). The registration constitutes "prima facie evidence" of the registrant's exclusive right to use the mark on the goods or services specified in the registration. But this evidentiary effect "shall not preclude an opposing party from proving any legal or equitable defense or defect which might have been asserted if such mark had not been registered." 15 U.S.C. § 1115(a) (1985).

${ }^{70}$ See, e.g., Flexitized, Inc. v. National Flexitized Corp., 335 F.2d 774, 779-80 (2d Cir. 1964), cert. denied, 380 U.S. 913 (1965).

"Notwithstanding the fact that section 2(f) of the Act permits registration of a descriptive mark only upon proof of its distinctiveness, it is possible, as a result of error in the registration process, for such a mark to be registered even though it lacks distinctiveness. Justice Stevens, dissenting in Park 'N Fly, cited administrative problems in the PTO as one reason why nondistinctive marks might erroneously get on the register. He noted that witnesses testifying before Congress had been overly sanguine about being able to avoid errors. He believed that registration of the Park 'N Fly mark constituted such an error, for it was a 
to permit it to be monopolized. By so interpreting the incontestability provisions, the Supreme Court in Park ' $N F l y$ put to rest the conventional view that the Lanham Act provides predominantly procedural benefits, without changing substantive rights derived from the common law. ${ }^{72}$ This was the view that had made previous courts reluctant to accept the incontestability provisions at face value. ${ }^{73}$

Park ' $N$ Fly was an action for service mark infringement by petitioner, an operator of long-term parking lots near airports in Boston, Cleveland, Houston, Memphis, San Francisco, and St. Louis, against respondent, who provided similar parking services only in Portland, Oregon. The petitioner's service mark consisted of the logo of an airplane and the words "Park 'N Fly." It was registered in 1971, and obtained incontestable status under section 15 of the Act almost six years later. The respondent operated under the name "Dollar Park and Fly."

Petitioner sought to enjoin respondent from using the words "Park and Fly" in connection with its business, and respondent counterclaimed, seeking cancellation of petitioner's registration, under section 14(c), on the ground that the registered mark was generic. In addition, respondent raised as defenses that the petitioner had no enforceable rights because its mark was merely descriptive under section 2(e); that, under section 33(b)(5), respondent was in privity with a Seattle corporation which had used the expression "Park and Fly" from a date prior to the registration of petitioner's mark; and that petitioner's mark was not infringed be-

merely descriptive mark that was registered without proof of distinctiveness under section 2(f). $105 \mathrm{~S}$. Ct. at $671 \mathrm{n.12}$ (Stevens, J., dissenting). The Court declined to determine whether the "mark [had been] improperly issued" [sic], because neither the district court nor the court of appeals had made any finding as to this. Id. at 664 n.5.

The mechanical character of the conditions under which incontestable status is obtained are set forth infra notes 94-96 and accompanying text.

72 Apart from the evidentiary advantages, see supra note 69 , the procedural benefits include federal jurisdiction, see 15 U.S.C. $\$ 1121$ (1985), and a procedure whereby a registered mark can be recorded with the Treasury Department in order to assist in the prevention of infringing imports, see id. $\S 1124$. The conventional view had its basis in the history of federal trademark legislation and the Supreme Court's reaction to it. See Trade-Mark Cases, 100 U.S. 82 (1879). This history is discussed in 1 J. Thomas McCarthy, supra note 6, $\S \S 5: 3-: 4$, at 135-42. Even before Park ' $N$ Fly, this view had become difficult to justify: for example, it had been established that the constructive notice doctrine, see Lanham Act $\S 22$, 15 U.S.C. $\$ 1072$ (1985), gave the owner of a registered trademark nationwide rights instead of the territorially restricted rights given by the common law. See Hanover Star Milling Co. v. Metcalf, 240 U.S. 403 (1916); United Drug Co. v. Theodore Rectanus Co., 248 U.S. 90 (1918); Dawn Donut Co. v. Hart's Food Stores, Inc., 267 F.2d 358 (2d Cir. 1959). 1961).

${ }^{73}$ See, e.g., John Morrell \& Co. v. Reliable Packing Co., 295 F.2d 314, 316 (7th Cir. 
cause there was no likelihood of confusion. The district court held that petitioner's mark was not generic, that a registrant's exclusive right to use an incontestable mark could not be challenged on the ground that it was merely descriptive, that privity with the Seattle corporation was not proved, and that likelihood of confusion was sufficiently demonstrated. Accordingly, petitioner was granted a permanent injunction. ${ }^{74}$ The court of appeals reversed on the ground that section $33(\mathrm{~b})$ provided no "offensive" right to enjoin respondent from using a similar mark, so that the exclusivity of petitioner's right could be challenged on the ground of mere descriptiveness. ${ }^{75}$

The Supreme Court reversed and remanded, holding that section $33(\mathrm{~b})$ could be used offensively by a registrant in an infringement action, and that a registrant's exclusive right could not be challenged for mere descriptiveness. ${ }^{76}$ The Court's decision thus stilled all doubts that the Lanham Act substantively alters the common law distinctiveness criterion. The majority read the legislative history of the Lanham Act ${ }^{77}$ as indicating that Congress acted in full awareness of the implications of the incontestability provisions. ${ }^{78}$ Although the evidence supporting this reading is ambiguous, ${ }^{79}$ it is arguably sufficient to tip the balance against the

34105 S. Ct. at 661.

78718 F.2d 327 (9th Cir. 1983).

${ }^{76} 105 \mathrm{~S}$. Ct. at 667 . On remand, the Ninth Circuit held that the registrant's incontestable exclusive right had in fact been infringed, for respondent's use of the mark "Dollar Park and Fly" was likely to cause confusion. 782 F.2d 1508, 1509 (9th Cir. 1986). For an explanation of infringement, see supra note 63.

7 The legislative history of the Act is extremely extensive. See Carter, The New Trade-Mark Act, 41 Trademark Bulletin 99 (1951). A useful summary may be found in Daphne Robert, The New Trademark Manual 228-37 (1947).

${ }^{38}$ The majority opinion noted that arguments against the granting of incontestable status to a merely descriptive mark had been addressed to Congress and rejected by it. It added that it was not persuaded by the dissent's attempt to disagree with the balance struck by Congress, because the Court's responsibility "[was] not to evaluate the wisdom of the legislative determinations reflected in the statute, but instead to construe and apply the provisions that Congress [had] enacted." $105 \mathrm{~S}$. Ct. at 666.

79 The most persuasive aspects of the legislative history involve three events. First, Congress was expressly alerted to the possibility and the dangers of a merely descriptive mark attaining incontestable status. Hearings on H.R. 82, Subcommittee of the Senate Committee on Patents, 78th Cong., 2d Sess. 59-60 (1944); Hearings on H.R. 102, Subcommittee on Trademarks of the House Committee on Patents, 77th Cong., 1st Sess. 106-07, 109-10, 175 (1941). Second, Congress expressly noted the alternative of specifically including descriptiveness among the "defenses or defects" listed in section 33(b), and did not adopt it. Hearings on S. 895, Subcommittee of the Senate Committee on Patents, 77th Cong., 2d Sess., 45, 47 (1942). Finally, the conference committee agreed to an amendment making genericness an exception to incontestability under section 15 , having rejected an amendment that would have prevented any merely descriptive mark from being registered at all 
dissenting view: that Congress intended simply to limit the time for asserting rival claims of ownership to a concededly valid trademark, and did not expect that its proposed solution would permit monopolization of something that, at common law, could not have been a valid trademark. ${ }^{80}$

\section{B. The Mechanics of the Incontestability Provisions}

The manner in which the incontestability provisions cut off challenges to a registered mark's distinctiveness is complex and needs careful explanation. Fundamentally, they do so by imposing a set of three interrelated limitation periods, each of which partially restricts a nonregistrant's ability to engage in certain conduct regarding the mark. ${ }^{81}$ After a certain period of time, section 14(c) restricts the ability to obtain cancellation of the registration; upon satisfying certain additional conditions, sections 15 and $33(\mathrm{~b})$, respectively, limit challenges to the registrant's rights to use the mark and to exclude others from using the mark.

Three limitation periods were necessary, first, because substantive rights to a mark are not derived from registration, ${ }^{82}$ and second, because an important objective of the Lanham Act is to provide, in the register, a reliable public record of existing substantive rights. ${ }^{83}$ Putting a registration beyond challenge would have been odd if the registrant's own use of the mark could still be enjoined, or if others could still resist being enjoined by it, and misleading because it would needlessly have discouraged others from using the mark. A three-pronged approach was therefore essential, but its efficient functioning required that the limitation periods be symmetrical. A mark whose registration is noncancellable should

even though it had acquired secondary meaning. H.R. Conf. Rep. No. 2322, 79th Cong., $2 \mathrm{~d}$ Sess. 4, 5 (1946). See Park ' $N$ Fly, 105 S. Ct. at 665. The dissent in Park 'N Fly did not find these aspects of the history to be persuasive, saying that Congress's failure to make descriptiveness one of the "defenses or defects" in section 33(b) resulted only from it having been lulled into the belief-misplaced, as it turned out-that a merely descriptive mark without secondary meaning was unlikely ever to be registered. $105 \mathrm{~S}$. Ct. at 670,674 .

so $105 \mathrm{~S}$. Ct. at $672-73$ (Stevens, J., dissenting).

si In contrast with the copyright and patent statutes, the Act contains no general statute of limitations. See 17 U.S.C. $\$ 507(b)$ (1982) (copyright); 35 U.S.C. § 286 (1982) (patent). In 1971, the American Bar Association's Section of Patent, Trademark, and Copyright Law proposed amending section 35 to provide for a four-year limitation period; so far, this has not been done. See Stimson, Statutes of Limitation in Trademark Actions, 71 Trade-Mark REP. 605 (1981).

${ }^{32}$ See supra note 69 and accompanying text.

ss This objective is often expressed in the maxim, "the right to register follows the right to use." It has been recognized that this must be qualified by the phrase, "as nearly as possible." See Application of E.I. Du Pont de Nemours \& Co., 476 F.2d 357 (C.C.P.A. 1973). 
also be substantively usable and protectable; conversely, a mark capable of use and protection should not be removable from the register. Unfortunately, this symmetry has not been achieved. ${ }^{84}$

1. Noncancellability. The Lanham Act provides two methods $^{85}$ by which a registration may be cancelled: by petition in the PTO under section $14,{ }^{86}$ and "[i]n any action involving a registered mark," under section $37 . .^{87}$ Neither provision specifies the grounds upon which cancellation may be sought, ${ }^{88}$ but since the underlying policy is to remove marks that have mistakenly found their way onto the register, every ground on which registration could originally have been denied is a ground for cancellation. ${ }^{89}$ After five years have elapsed since the date of registration, however, section $14(c)$ narrows the grounds available for cancellation, ${ }^{90}$ principally

84 See infra notes 105-09 and accompanying text.

${ }^{85}$ Apart from the two methods set forth and discussed infra at notes 86-92 and accompanying text, there are also, under sections 8 and 9 of the Act, respectively, provisions for automatic removal from the register after six years and for expiration of the registration after 20 years, unless renewed. 15 U.S.C. $\$ \S 1058,1059$ (1985).

${ }^{88}$ The Act provides that "[a] petition to cancel a registration of a mark . . . may . . . be filed by any person who believes that he is or will be damaged by the registration." 15 U.S.C. $\$ 1064$ (1985). Standing to seek cancellation under this provision is available to anybody who is not merely an intermeddler, and who shows "a personal interest in the outcome beyond that of the general public." Lipton Indus., Inc. v. Ralston Purina Co., 670 F.2d 1024, 1028-29 (C.C.P.A. 1982).

${ }^{87}$ In relevant part, section 37 of the Act reads as follows:

In any action involving a registered mark the court may determine the right to registration, order the cancellation of registrations, in whole or in part, restore canceled registrations, and otherwise rectify the register with respect to the registrations of any party to the action.

15 U.S.C. $\$ 1119$ (1985). Cancellation under this section may be sought only "[i]n [an] action involving a registered mark." This has been interpreted as meaning that the court's jurisdiction must rest on some basis other than the cancellation claim itself. See Universal Sewing Mach. Co. v. Standard Sewing Equip. Corp., 185 F. Supp. 257, 260 (S.D.N.Y. 1960). A cancellation counterclaim may therefore be made by the defendant in an infringement action. See Jack Daniel Distillery, L.M.P., Inc. v. Hoffman Distilling Co., 298 F.2d 606, 607 (6th Cir.), cert. denied, 370 U.S. 939 (1962).

${ }^{88}$ The Act does not specify the grounds upon which cancellation may be sought under section 14 within the first five years of the registration, 15 U.S.C. $\$ 1064$ (a) (1985). This omission has, however, been supplied by "administrative and judicial interpretation." See 1 J. Thomas McCarthy, supra note 6, § 20:14, at 1053-54. Section 37, which contains no specific time limit, is similarly silent as to cancellation claims made at any time, but it may be the implication of the majority opinion in Park ' $N$ Fly that such claims should be based on the same grounds as those under section 14(a). See infra note 90.

89 See International Order of Job's Daughters v. Lindeburg \& Co., 727 F.2d 1087, 1091 (Fed. Cir. 1984). The principal grounds among these are the statutory bars to registration in section 2 of the Act. See 15 U.S.C. \$ 1052 (1985). In addition, cancellation can also be sought, within the first five years, on the grounds available "at any time" under the Act. See infra note 90.

so The grounds upon which cancellation may be sought "at any time" are specified in section 14(c), (d), and (e) of the Act, of which the last two sections apply only to registra- 
by excluding the most important ones, priority and nondistinctiveness. ${ }^{91}$ Persistent attempts to reintroduce these as grounds of cancellation have, on the whole, been unsuccessful. ${ }^{92}$ Challenges to the registration by a prior user of the registered mark, or by a user claiming that the mark is nondistinctive, are therefore impossible once the registration is five years old.

2. Incontestability. For the purpose of dealing with challenges to the registrant's substantive rights in relation to the registered mark, the Act distinguishes between the right to use the mark and the right to exclude others from using it. Section $15^{33}$ provides that a registrant's right to use the mark in commerce, on certain goods or services, becomes incontestable if three criteria are met. The mark must have been "in continuous use"

tions under previous statutes and to certification marks, respectively, and are of no further concern here. Section 14(c) provides that cancellation may be sought:

at any time if the registered mark becomes the common descriptive name of an article or substance, or has been abandoned, or its registration was obtained fraudulently or contrary to the provisions of section 1054 of this title or of subsections (a), (b), or (c) of section 1052 of this title for a registration hereunder, or contrary to similar prohibitory provisions of said prior Acts for a registration thereunder, or if the registered mark is being used by, or with the permission of, the registrant so as to misrepresent the source of the goods or services in connection with which the mark is used ... .

15 U.S.C. $\S 1054$ (c) (1985). It will be seen that the principal grounds that are not available "at any time" are the statutory bars to registration in section 2(d) and (e), though there are others, such as failure to have used the mark in commerce prior to registration. Note that functionality of the mark, unlike its generic character, is not one of the grounds specifically mentioned.

Until Park ' $N F l y$, it was uncertain whether the grounds for a cancellation claim under section 37 were narrowed similarly after five years. The dissent argued that all grounds should remain available, so as to enable courts always to review PTO actions and to correct its errors in granting registrations. $105 \mathrm{~S}$. Ct. at $671 \mathrm{n} .12$ (Stevens, J., dissenting); see also supra note 71. But the majority disagreed, insisting that the wide language of section 37 had to be made subject to the specific provisions of section 14(c). $105 \mathrm{~S}$. Ct. at 666 .

"See 1 J. Thomas McCarthy, supra note 6, § 20:14, at 1054.

92 For example, an attempt has been made to use section 2(a) ("falsely [to] suggest a connection with persons") in order to evade the unavailability of prior use under section 2(d) as a ground for cancellation. See Morehouse Mfg. Corp. v. J. Strickland \& Co., 407 F.2d 882, 888-89 (C.C.P.A. 1969); Popular Merchandise Co. v. "21" Clubs, Inc., 343 F.2d 1011, 1015 (C.C.P.A. 1965). This has been foiled by requiring the would-be canceller to prove not only a likelihood of confusion, but also an intent, on the registrant's part, to take a free ride on the prior user's goodwill. See Dynachem Corp. v. Dexter Corp., 203 U.S.P.Q. 218, 220 (T.T.A.B. 1979); University of Notre Dame Du Lac v. J.C. Gourmet Food Imports Co., 703 F.2d 1372, 1377 (Fed. Cir. 1983).

๑3 15 U.S.C. $\$ 1065$ (1985).

"This "continuous use" is probably the same as the "continuing" use required under section 15 of the Act in order to establish an exception to the incontestable right to use, which is discussed infra note 98 and accompanying text. Such "continuing" use has been held to mean use without any significant interruption, rejecting the argument that it is the same as an absence of abandonment. See Casual Corner Assocs., Inc. v. Casual Stores of Nevada, Inc., 493 F.2d 709, 712 (9th Cir. 1974). But see Cuban Cigar Brands N.V. v. 
connection with those goods or services for five consecutive years after registration, ${ }^{95}$ it must still be in such use, and the registrant must have filed the required affidavit. ${ }^{96}$ No incontestable right to use arises if the registration is cancellable, ${ }^{97}$ or to the extent that the registrant's use would infringe another person's valid common law rights, acquired as a result of the latter's continuing use of a mark since before the registration of the registered mark. ${ }^{98}$ This "defensive" aspect of incontestability gives the registrant, subject to the two limitations mentioned, a shield to resist any attempt to enjoin its continued use of the registered mark, but does not protect its right to exclude others from using that mark.

This latter right is rendered unchallengeable by the "offensive" aspect of incontestability contained in section 33(b), ${ }^{99}$ which comes into operation only when an incontestable right to use the registered mark has arisen under section 15 . When this occurs, section $33(b)$ provides that "the registration shall be conclusive evi-

Upmann Int'l, Inc., 457 F. Supp. 1090, 1100-01 (S.D.N.Y. 1978). The same meaning probably applies also to "continuously used" in section $33(b)(5)$. See 15 U.S.C. § $1115(b)(5)$ (1985).

${ }^{93}$ Any five consecutive years after the registration will suffice, not necessarily the first five. The incontestable right to use, therefore, may arise for the first time more than five years after the date of the registration; contrast this with ron-cancellability under section 14(c) of the Act, which must arise as soon as the mark has been on the register for five years. See 15 U.S.C. § 1064(c) (1985).

(6) The affidavit must set forth the goods or services stated in the registration on or in connection with which the mark has been in the requisite continuous use, that the registrant's claim to ownership of the mark and its right to register it or keep it on the register have not been the subject of any final adverse decision, and that there is no pending proceeding involving these rights. 15 U.S.C. $\$ 1065(3)$ (1985). Note that there is no procedure for the PTO to verify the truth of the statements made in a $\$ 15$ affidavit, nor for its publication, nor for any opposition to it. See supra note 71 . The affidavit requirement means that the incontestability of the right to use, unlike noncancellability of the registration, does not arise automatically upon the expiration of a defined period of time.

${ }^{97}$ For the grounds of cancellation available after registration for five years, see supra note 90. No incontestable right to use can thus be acquired in a mark that falls within the statutory bars to registration contained in section 2(a), (b), and (c) of the Act. See 15 U.S.C. $\S 1052(a)$, (b), and (c) (1985). This does not mean, of course, that the registrant's continuing use of the mark can necessarily be enjoined: it merely makes that right contestable.

${ }^{83}$ The "pre-registration use" required by this exception to incontestability may have commenced earlier than the registrant's use, making the pre-registration user the senior user. Or it may have commenced after the registrant's use but before the registrant's registration, making the pre-registration user an "intermediate junior user," in Professor McCarthy's terminology. See 2 J. Thomas McCARTHY, supra note $6, \S 26: 18$, at 323 . Although this exception to incontestability appears to apply to both situations, in fact the latter situation, involving an intermediate junior user, is governed by the more specific language of section 33(b)(5) of the Act. See 15 U.S.C. \& 1115(b)(5) (1985); see also Travelodge Corp. v. Siragusa, 228 F. Supp. 238, 242 (N.D. Ala.), aff'd per curiam, 352 F.2d 516 (5th Cir. 1966).

จ9 15 U.S.C. \& 1115 (b) (1985). 
dence $^{100}$ of the registrant's exclusive right to use the registered mark in commerce"101 in connection with the goods or services specified in the section 15 affidavit, unless one of a number of listed "defenses or defects" is established. ${ }^{102}$ If no such defense or defect is provable, a defendant in an infringement suit brought by the registrant is precluded from defending on the ground that the registrant lacks the right to exclude all others from using the mark in commerce in connection with the specified goods or services, although other defenses remain open. ${ }^{103}$

${ }^{100}$ No one has suggested that the fact that section 33(b) uses the words "conclusive evidence" instead of the words "incontestable" has any relevance. See supra note 11.

102 See Holiday Inn v. Holiday Inns, Inc., 189 U.S.P.Q. 630 (C.C.P.A. 1976). The court interpreted the phrase "the registrant's exclusive right to use the mark in commerce,"which appears in Lanham Act § 7(b), 15 U.S.C. § 1057(b) (1985), to mean that the registrant had a right to prevent others from using the registered mark without necessarily having a right to use it himself. 189 U.S.P.Q. at 635. This is analogous to the position under the Patents Act, 35 U.S.C. $\S 154$ (1982). Exactly the same phrase is used in section $33(a)$ and (b) of the Lanham Act.

102 The status of the "defenses or defects" in section 33(b) remains unclear, as does that of other certain defenses that are not specifically mentioned, especially equitable ones. The majority opinion in Park ' $N$ Fly expressly refused to decide whether these continue to be available. $105 \mathrm{~S}$. Ct. at 666; see infra text accompanying notes 110-25.

${ }^{103}$ The offensive use of section 33(b) is clearly suggested by the contrast between its language and that of section 15, and plainly contemplated by section $33(b)(4)$, (5), and (6). Nevertheless, because such use has the effect of allowing the registrant to monopolize a descriptive mark, despite its lack of distinctiveness, arguments were persistently made, before Park 'N Fly, that it could only be used defensively, to protect the registrant from attempts to enjoin its continued use or to cancel its registration. See, e.g., Lindy Pen Co. v. Bic Pen Corp., 725 F.2d 1240, 1247 (9th Cir. 1984); Prudential Ins. Co. v. Gibraltar Financial Corp., 694 F.2d 1150, 1153 (9th Cir.), cert. denied, 463 U.S. 1208 (1983); Tillamook Country Creamery v. Tillamook Cheese \& Dairy Ass'n, 345 F.2d 158, 163 (9th Cir.), cert. denied, 382 U.S. 903 (1965); John Morrell \& Co. v. Reliable Packing Co., 295 F.2d 314, 316 (7th Cir. 1961). These arguments originated in a statement in the PTO in a cancellation proceeding, Rand McNally \& Co. v. Christmas Club, 105 U.S.P.Q. 499, 500 (1955), aff'd, 242 F.2d 776 (C.C.P.A. 1957), in which Assistant Commissioner Leeds stated that incontestability did not give the registrant "an 'offensive weapon' of any greater magnitude than it has had since the registration issued." Id. at 501. The Seventh Circuit treated this as meaning that section 33(b) could not be used offensively, see John Morrell, 295 F.2d at 316, although, as it has been pointed out, this involves ripping the statement, which "verged on dicta," "brutally out of context." Fletcher, supra note 5, at 95. More recently, a purely defensive view of section 33(b) was taken by the Ninth Circuit. Lindy Pen Co., 725 F.2d at 1247; Park 'N Fly, 718 F.2d at 331; Prudential Ins. Co., 694 F.2d at 1153. In Prudential Ins. $C a$, the court said merely that to allow section $33(b)$ to be used offensively would be to read the Lanham Act broadly, which it preferred not to do, for it would invite "anticompetitive and irrational market behavior." 694 F.2d at 1153. As examples of its narrow reading of the Act, the court cited Smith v. Chanel, Inc., 402 F.2d 562 (9th Cir. 1968), and International Order of Job's Daughters v. Lindeburg \& Co., 633 F.2d 912 (9th Cir.), cert. denied, 452 U.S. 941 (1981).

The Seventh Circuit took the view that section 33(b) could be used offensively. Union Carbide Corp. v. Ever-Ready Inc., 531 F.2d 366, 377 (7th Cir.), cert. denied, 429 U.S. 830 (1976). Shortly after Union Carbide, the Second Circuit arrived independently at the same 
3. The Incontestability Provisions in Operation. The way incontestability operates can best be seen from the point of view of a nonregistrant wishing to challenge both the registration and the substantive rights of a registrant after the mark has been registered for five years, has been "in continuous use" in commerce in connection with certain goods or services, and the appropriate affidavit has been filed. The change from the common law becomes apparent when one considers the prospects of a challenge based upon the alleged descriptiveness of the mark. Such a challenge will fail on all counts. The challenger cannot cancel the registration, for mere descriptiveness (unlike genericness) is not a ground for cancellation "at any time" under section $14(\mathrm{c}) .^{104}$ The challenger cannot enjoin the registrant's use of the mark under section 15 , for neither the challenger nor anyone else can have a common law right in a nondistinctive mark that would be infringed by the registrant's continued use of the mark. Finally, since the registrant has an incontestable right to use the mark, and mere descriptiveness is not one of the "defenses or defects" listed in section $33(\mathrm{~b})$, the challenger cannot attack the registrant's right to exclude all others from using the mark. The registrant's rights to keep the mark on the register, and to use and protect it despite its descriptiveness, are therefore impervious to attack.

Quite different results follow, however, if the challenge is based on prior use of the registered mark. The registration will not be cancellable here either, but the registrant's right to use the mark will be contestable to the extent that such use would infringe the challenger's valid common law rights derived from the latter's

conclusion. Abercrombie \& Fitch Co. v. Hunting World Inc., 537 F.2d 4, 12 (2d Cir. 1976). The Union Carbide rationale was followed in United States Jaycees v. Philadelphia Jaycees, 639 F.2d 134, 137 (3d Cir. 1981), and in Soweco, Inc. v. Shell Oil Co., 617 F.2d 1178, 1185 (5th Cir. 1980), cert. denied, 450 U.S. 981 (1981).

The Supreme Court granted certiorari in Park 'N Fly, 465 U.S. 1078 (1984), to resolve this direct conflict between the Seventh and Ninth Circuits. The majority in Park 'N Fly asserted that "[o]ne searches the language of the Lanham Act in vain to find any support for the offensive/defensive distinction," $105 \mathrm{~S}$. Ct. at 662 , and endorsed the validity of an offensive use of section $33(\mathrm{~b})$, id. at 663 . Strictly speaking, it is false to say that the Lanham Act contains no distinction between offensive and defensive use, for the distinction relating to incontestability between sections $33(\mathrm{~b})$ and 15 is precisely such a distinction. Section 33(b) is intended for offensive use by the registrant, and section 15 for defensive use. Earlier cases had sought to impose such a distinction upon section 33(b) itself, thus disabling the registrant from using it offensively.

${ }^{104}$ Cancellation of a registration can always be sought on the ground of genericness-i.e., on the ground that the registered mark has become the "common descriptive name of an article or substance." See supra note 90 . Genericness also prevents the acquisition of incontestability. See infra note 114 and accompanying text. 
"pre-registration use" of the mark. ${ }^{105}$ The challenger can therefore enjoin the registrant's use of the mark: in a particular area, if its common law right is geographically limited, ${ }^{108}$ or anywhere, if its right is nationwide. ${ }^{107}$ Since the registrant's right to use will have failed to become incontestable, its right to exclude others also remains challengeable under section 33(b).

The registrant faced with a prior user can thus preserve its registration, but its substantive rights to use and protect the mark are open to challenge. A successful challenge may preclude it from using the registered mark, exclusively or concurrently with the prior user, in a defined area or nationwide. ${ }^{108}$ Thus, the common law principle that priority of use determines ownership ${ }^{109}$ of a mark is unaffected by incontestability. This difference in results illustrates the limitations of the incontestability provisions.

\section{Softening the Impact of Incontestability}

The Lanham Act's impact upon a nonregistrant wishing to use a descriptive mark that is registered and has attained incontestable status may be less drastic than indicated above if the incontestability provisions are counterbalanced by other provisions of the Act. One possible source of balance is in the Act's defenses, many of which are available notwithstanding incontestability.

It can be argued that the registrant's monopoly of the descriptive mark does not really enable it to prevent others from using this competitively valuable mark, since other users normally can escape liability on the basis of one of these defenses. Assessment of this argument requires a clear understanding of the nature of the

${ }^{103}$ See supra note 98 and accompanying text.

${ }^{108}$ See D. RoBert, supra note 77, at 141-42. This effect of the exception has been widely accepted. See Armand's Subway, Inc. v. Doctor's Assocs., Inc., 604 F.2d 849, 850 (4th Cir. 1979); Wrist-Rocket Mfg. Co. v. Saunders Archery Co., 578 F.2d 727, 730 (8th Cir. 1978); Value House v. Phillips Mercantile Co., 523 F.2d 424, 430-31 (10th Cir. 1975); Burger King of Florida, Inc. v. Hoots, 403 F.2d 904, 907 (7th Cir. 1968).

${ }^{107}$ See Cuban Cigar Brands N.V. v. Upmann Int'l, Inc., 457 F. Supp. 1090, 1100 (S.D.N.Y. 1978).

${ }^{108}$ If this happens, the register ceases to provide an accurate record of existing substantive rights. See supra notes 83-84 and accompanying text.

109 "The cases are legion to the effect that for inherently distinctive marks, ownership is governed by priority of use." $1 \mathrm{~J}$. Thomas McCARThy, supra note $6, \S 16: 2$, at 721. For marks that are not inherently distinctive, but have become distinctive, ownership depends upon the party that first made the mark distinctive of itself. See National Color Laboratories, Inc. v. Philip's Foto Co., 273 F. Supp. 1002, 1003 (S.D.N.Y. 1967). This is the logical test, but courts have in fact required the first person to commence use to prove that the mark had already become distinctive of it at the time that the later use commenced. See Scott Paper Co. v. Scott's Liquid Gold, Inc., 589 F.2d 1225, 1231 (3d Cir. 1978). 
defenses, the most important of which are found in section 33(b)'s "laundry list."110 Each of these is an exception to the incontestability of the registrant's exclusive right to use the mark. ${ }^{111}$ Additional exceptions-or, more accurately, grounds preventing incontestability from arising at all-have their source in sections 15 and 14(c). Incontestability of the registrant's exclusive right to use the mark arises only when its right to use the mark has become incontestable under section $15 .^{112}$ This does not occur if a ground exists for cancelling the registration "at any time" under section 14(c), or with respect to anyone whose common law rights from preregistration use of some mark or trade name would be infringed by use of the registered mark. ${ }^{113}$ The two sets of exceptions overlap in part, but a few of them-genericness of the registered mark, ${ }^{114}$ prior use of it or of a confusingly similar mark, ${ }^{115}$ and the presence of prohibited matter in the mark ${ }^{116}$ - expand a defendant's ability to contest the registrant's exclusive right.

An exception to incontestability may or may not be a defense on the merits to an infringement action. Whether this is so is irrelevant to a defendant charged with infringing an incontestable descriptive mark, for proof of an exception renders the exclusivity of the registrant's right to use the mark contestable; the defendant can then contest it on the basis of the mark's lack of distinctiveness. ${ }^{117}$ The extent to which these exceptions undercut the incontestability provisions, therefore, depends upon the likelihood that the defendant can establish any of them. This probability is low, since the mark's descriptiveness is inconsistent with some excep-

110 The phrase comes from Justice Stevens. Park 'N Fly, 105 S. Ct. at 674 (Stevens, J., dissenting).

111 See infra note 117 and accompanying text.

112 See supra notes $93-103$ and accompanying text.

11 See supra notes 97-98 and accompanying text.

114 This is not an exception under section 33(b) of the Act, but becomes one by virtue of being an available ground for cancellation under section 14(c), as well as being specifically mentioned in section 15(4). See supra notes 90, 98, 104.

11 Section 15 of the Lanham Act makes pre-registration use with common law rights an exception, and thus adds to section $33(\mathrm{~b})(5)$ to the extent that it applies also to the case of prior use; section $33(\mathrm{~b})(5)$ applies only to an intermediate junior user. See supra note 98.

${ }^{116}$ Lanham Act, § 2(a), (b), (c), 15 U.S.C. § 1052(a), (b), (c) (1985). They become exceptions by virtue of being grounds for cancellation under section 14(c).

117 This is a "plain language" interpretation of the "defenses or defects" of section 33(b): the section provides that "the registration shall be conclusive evidence . . . except when one of the following defenses or defects is established." 15 U.S.C. § 1115(b) (1985) (emphasis added). But it has strong support in the legislative history of the Act. See 92 Cong. REc. 7524 (June 25, 1946) (statement of Rep. Lanham); Carl Zeiss Stiftung v. V.E.B. Carl Zeiss, Jena, 298 F. Supp. 1309, 1315 (S.D.N.Y. 1969). It was also endorsed by the majority in Park 'N Fly. 105 S. Ct. at 664 n.6. 
tions $^{118}$ and irrelevant to others. ${ }^{119}$ The only two exceptions that might plausibly be established precisely because of the mark's descriptiveness are abandonment and fair use: abandonment, because in its "unintentional" aspect ${ }^{120}$ it occurs when a course of conduct has caused the mark to lose its distinctiveness; and fair use, ${ }^{121}$ because the very thing this exception contemplates is a particular method of using a descriptive mark.

Despite their superficial plausibility, it is unlikely that the defendant will be able to establish either exception. Unintentional abandonment requires not merely the absence of distinctiveness but its loss: moreover, a loss brought about by the registrant's conduct. ${ }^{122}$ Typically, it occurs in cases involving uncontrolled licensing, failure to act against infringers, assignment of a mark without goodwill, or failure to police the use of a mark resulting in its becoming generic. ${ }^{123}$ It does not occur where the registered mark has always been nondistinctive and the registrant's conduct cannot be impugned. ${ }^{124}$

It is equally unlikely that the defendant will be able to prove fair use, at least if the descriptive mark is being used as a trademark, so as to convey its direct information to as many buyers as cheaply as possible. Since fair use means use other than as an "attention-getting symbol," the protection it offers competitors comes at the high price of their eschewing the most competitively valuable uses of the mark. ${ }^{125}$

In sum, the statutory exceptions to incontestability do little to

11 The defendant is unlikely to be an earlier registrant of the registered mark, see Lanham Act, $\S 33(b)(6), 15$ U.S.C. $\$ 1115(b)(6)$ (1985), or to have acquired common law rights as a result of pre-registration use of it, see Lanham Act, $\S 15,33(\mathrm{~b})(5), 15$ U.S.C. $\S \S 1065,1115(b)(5)$ (1985), or to have used the descriptive mark to misrepresent the source of its goods, see Lanham Act, $\$ \S 14(c), 33(b)(3), 15$ U.S.C. $\$ \S 1064(c), 1115(b)(3)(1985)$.

119 Lanham Act, $\S 33(\mathrm{~b})(1)$ (fraud), (7) (antitrust violation), 15 U.S.C. $\S \S 1115(b)(1)$, (7) (1985). The exceptions under $\S 2(a),(b),(c), 15$ U.S.C. $\S 1052(a),(b),(c)(1985)$, are probably also irrelevant: the registered mark may, of course, comprise prohibited matter, but the probability that it may do so is unaffected by its descriptiveness.

120 "Unintentional abandonment" contrasts with "intentional abandonment": the latter occurs when use of the mark has been discontinued with intent not to resume it, and the former when the registrant's conduct causes the mark to lose its significance as an indication of origin. See Lanham Act, § 45(a), (b), 15 U.S.C. § 1127(a), (b) (1985) (defining "abandoned").

${ }^{121}$ Lanham Act, § 33(b)(4), 15 U.S.C. § 1115(b)(4) (1985); see supra notes 64-66 and accompanying text.

122 See supra note 120.

123 See $1 \mathrm{~J}$. Thomas McCARTHY, supra note 6, § 17:2, at 769-70.

124 This is because courts have construed the statutory definition of "abandoned" very strictly. See Exxon Corp. v. Humble Exploration Co., 695 F.2d 96, 99-102 (5th Cir. 1983).

${ }^{125}$ See supra notes 64-66 and accompanying text. 
mitigate the effects of the incontestability provisions upon sellers who wish to use descriptive marks that are registered. They provide no reason to suppose that the private and social harms of permitting the monopolization of such marks will be insignificant.

\section{The Evaluation of Incontestability}

In the preceding sections, it has been shown that monopolization of descriptive marks by particular sellers would seriously disadvantage their competitors by creating formidable informational barriers between the competitors and their potential customers. The common law's distinctiveness requirement for property rights in a trademark reflects this fact. The withdrawal of descriptive marks from the public domain, through incontestability or otherwise, can therefore be justified only by demonstrating some compelling countervailing interest. With this in mind, it is now possible to evaluate possible justifications incontestability provisions of the Lanham Act's distinctiveness criterion.

\section{A. Incontestability and Adverse Possession}

The usual justification for incontestability is that it is necessary to quiet the registrant's title to the mark. ${ }^{126}$ This suggests that the considerations supporting incontestability are analogous to those permitting acquisition of title to real property by some period of adverse possession. This suggestion deserves serious attention, but has so far received little: no systematic attempt has yet been made to determine whether the policies underlying adverse possession also apply to trademarks. ${ }^{127}$ Careful examination suggests that incontestability cannot be rationalized on this basis.

Two justifications are commonly offered for granting title to land by adverse possession. The first, or "evidentiary," rationale asserts that evidence decays over time, making it impossible to judge accurately between competing claims. ${ }^{128}$ The second, or "holdout," rationale maintains that the true owner may lie in wait until the adverse possessor has increased the property's value by

${ }^{128}$ See Ooms \& Frost, Incontestability, 14 Law \& Contemp. Probs. 220, 223 (1949); see also Park ' $N$ Fly, $105 \mathrm{~S}$. Ct. at 664 (noting the references to this justification in the Act's legislative history).

127 These policies have recently, and comprehensively, been surveyed by Merrill, Property Rules, Liability Rules, and Adverse Possession, 79 Nw. U.l. REv. 1122 (1985). Among the more valuable of the earlier accounts is Charles Callahan, Adverse Possession 79-111 (1961).

${ }^{128}$ Merrill, supra note 127 , at 1128. 
sinking substantial resources into it, then hold out for settlement at a price that includes a substantial rent component. ${ }^{129}$ Both rationales are rooted in a concern for fairness to the adverse possessor. It would be unfair to expose the adverse possessor to challenges to his rights resolvable only on the basis of unsatisfactory evidence of events long past. It would also be unfair to expose him to ambushes by the true owner, whose late emergence is probably attributable only to his desire to share in the additional value resulting from the adverse possessor's activities on the property. ${ }^{130}$

Each of these rationales for adverse possession also, however, reflects considerations of social utility. Foreclosing all challenges to the adverse possessor's rights in land after a certain period of time advances society's interest in promoting transactions in that land by reducing uncertainty over its title, which in turn reduces information and transaction costs. According to the evidentiary rationale, this results from the fact that true owners are required to assert their proprietary claims promptly, before evidence grows stale; and according to the holdout rationale, from the removal of old claims that would otherwise constitute clogs upon the title, and might have to be bought out at opportunistic prices, thus reducing the value of the property. ${ }^{131}$

120 Professor Merrill treats this argument as merely one part of a wider justification for adverse possession, which he calls the "quieting title" rationale. According to this rationale, it is desirable to cut off old claims even when they are valid and discoverable, because to allow them to persist would require expending resources to discover them or insure against them, and would give their owners the opportunity to behave exploitatively. Id. at 1129. In the present article, attention is focused upon the latter of these two aspects, because it is the one that has most frequently been connected with incontestability. See infra note 133.

${ }_{130}$ Professor Merrill regards the evidentiary, though not (it seems) the quieting title, rationale as being based upon fairness concerns. See Merrill, supra note 127, at 1128-30.

1s1 Id. Professor Merrill also discusses two other arguments for adverse possession, based (respectively) upon the ideas that the true owner has slept on his rights and that the adverse possessor has built up expectations and he has continued to possess the land. Like the other rationales, each of these arguments has an individual as well as a social dimension. Individually, the sleeping-on-rights argument asserts that it would be unfair to allow the passive true owner to keep the title to the land as against the active adverse possessor, and the reliance argument asserts that it would be unfair to frustrate the adverse possessor's expectations, particularly because he is likely to have become emotionally attached to the land. Socially, both arguments rest upon the desirability of promoting market transactions in land. The penalization of those who are wholly inactive, in the sense required by the law, promotes such transactions because it encourages landowners to make themselves visible to potential transactors, thus reducing the cost of transacting. See infra note 150 and accompanying text. The protection of the adverse possessor's reliance, particularly when it has taken the form of investment in the land, promotes transactions by discouraging rent-seeking behavior and ensuring that the transaction takes place at market, rather than opportunistic, prices. See Merrill, supra note 127, at 1130-31.

Neither of these arguments is considered in the text, because their several bases are 
Both of the evidentiary and holdout rationales, in their individual as well as social dimensions, apply forcefully to challenges to the registrant's title to the mark. Such challenges require the identification of the first user of the mark, or of the first to make the mark distinctive. ${ }^{132}$ These determinations become increasingly difficult with the passage of time, as the quality of the available evidence deteriorates. There is a real risk that a prior user may lie in wait until the registrant has invested so much in his enterprise that he becomes vulnerable to exploitation. ${ }^{133}$ It is clearly desirable from society's standpoint that such claims be asserted promptly or be foreclosed, so as to obviate expensive investigations into their merits and even more expensive measures to buy them out. Individual fairness would be advanced, and market transactions in the registered mark would be facilitated, if incontestability were clearly to cut off, after the expiration of a certain period of time, the possibility of making title challenges to the registrant's property rights in the mark.

Ironically, however, this is precisely the kind of challenge that Lanham Act incontestability does not eliminate. A prior user remains able, in some circumstances, to assert the existence of a superior right despite the mark's attainment of incontestable status. ${ }^{134}$ Incontestability only eliminates challenges to validity, where the registrant's property right is attacked on the ground that the mark lacks distinctiveness and is therefore incapable of

either irrelevant to incontestability or subsumed under the evidentiary or holdout rationales. The unfairness of allowing the passive true owner to prevail, which is debatable even in the case of land, is barely arguable in connection with descriptive symbols that have not become distinctive, for the true owner in their case is the public in general, whose passivity consists merely in a failure to oppose the registration or seek its cancellation at a time when no individual member of the public had the incentive to take those actions. See infra note 148 and accompanying text. Such a failure hardly merits treatment as culpable neglect, punishable by forfeiture of the common right and withdrawal of the mark from the public domain. Similarly, and despite appearances to the contrary, it is not necessarily unfair to frustrate the expectations of the registrant of such a mark. These expectations are unilateral ones, to which the public has not contributed by any default on its part, and arguably they should not be allowed, in the absence of any other reasons, to alter the established pattern of entitlements. See Merrill, supra note 127, at 1132; see also infra notes 146-47 and accompanying text. The social dimension of the two arguments is the same as that of the evidentiary and holdout rationales, and is criticized infra at text accompanying note 137 .

132 See supra note 109.

${ }^{133}$ The legislative history of the Lanham Act shows that there was much concern in Congress about such "ambushes" and a strong desire to eliminate them. See, e.g., Hearings on H.R. 4744 Before the Subcomm. on Trademarks of the House Comm. on Patents, 76th Cong., 1st Sess. 106-07 (1939) (statement of Edward S. Rogers).

134 See supra notes 105-07 and accompanying text. 
being monopolized. ${ }^{195}$ Yet neither rationale for adverse possession has much (if any) relevance in this context.

This is particularly clear when the two rationales are considered in their individual aspects. No unfairness to the registrant results from his continuing exposure to challenges to the mark's validity. Such challenges are based upon offers to prove that the mark is currently nondistinctive; therefore, there is no risk that the registrant will lose his rights because evidence of past events is unavailable or misinterpreted. Furthermore, challenges to a descriptive mark's validity will seldom come as a complete surprise to its registrant; and because such challenges will usually be made by one who wishes to use the mark himself, there should be little danger that the challenger will offer to be bought out at an extortionate price. The elimination of validity challenges cannot, therefore, be justified in the name of individual fairness. ${ }^{138}$

The matter becomes more complex, however, when considered from the standpoint of social utility. It is undoubtedly arguable that eliminating validity challenges reduces the costs that potential assignees or licensees might otherwise incur in investigating distinctiveness, and thereby facilitates market transactions in the registered mark. ${ }^{137}$ But that argument does not support eliminating such challenges, for the increased marketability of a descriptive mark is not necessarily a socially beneficial objective. The common law places such marks in the public domain, and views it as neither necessary nor desirable to permit private property rights in them. Consequently, it is uninterested in claims that a particular measure or policy ought to be supported because it would make these rights, if created, freely transferable and attractive in the marketplace. Incontestability reverses the common-law rule. This result may indeed be a good one, but if this is to be demonstrated, and not merely assumed, it is necessary first to justify the creation of property rights in descriptive marks: it is not sufficient simply to note that incontestability leads to a result that would be desirable, if creating such rights were justified. Such justification, if it exists, must be sought in theories concerning the fundamental bases of property rights, rather than in approaches based upon analogies to statutes of limitation, which address only the desirability of shifting an extant property right from one person to another.

1s3 See supra note 104 and accompanying text.

1s6 See supra note 131 for discussion of the fairness concerns underlying the sleepingon-rights and reliance rationales.

137 See supra text accompanying note 131 for such arguments in relation to land. 


\section{B. Incontestability and Theories of Property Rights}

1. Economic Theories. The economic theory of property rights asserts that the creation of a property right in a resource is justified by the need, statically, to direct the resource to its highest-valued use, and dynamically, to ensure its optimal utilization and proper development. ${ }^{138}$ These objectives cannot be achieved unless the resource is subjected to exclusive control. In the absence of such control, it cannot be directed to its highest-valued use, for the bidding-up process essential to such direction cannot occur. It cannot be optimally utilized, for each user's private costs will be lower than the social costs associated with his use, and this difference will lead to overutilization. ${ }^{139}$ Finally, the resource cannot be properly developed, because no one will invest in development without some assurance of reaping the fruits of that investment. ${ }^{140}$

This theory of property rights is powerful and persuasive, but breaks down in the case of a descriptive mark. The reason for this is that such a mark is not a scarce resource. Since one person's use of a descriptive mark does not affect its availability (either quantitatively or qualitatively) to other users, there is no static allocation problem, and no dynamic utilization problem requiring for its solution the creation of a property right. ${ }^{141}$ Nor is there any development problem that would be solved by recognizing property rights in such marks. It is true that, in the absence of these rights, sellers are deterred from adopting descriptive marks and from investing resources to make them distinctive. But there is nothing wrong with this result. Expenditure on trademarks-or their "development"-is not desirable for its own sake, but because trademarks, once they become distinctive, provide a secure means of identifying the source of goods. This enables sellers to capture the

${ }^{138}$ See Richard Posner, Economic Analysis of Law 30-33 (3d ed. 1986).

139 This will be so because, when the resource is communally owned, each person's exercise of his communal right will impose costs not only upon him, but also upon others-for example, if, in a pasture open to all, a herdsman decides to keep an extra cow, this decision will involve some costs that he will have to pay himself, and other costs (arising from the fact that the pasture will now be more crowded) that will be borne by other herdsmen. These external costs will not be taken into account by any user in determining the scale of his activities, which will therefore be carried on at a super-optimal level. See Demsetz, Toward a Theory of Property Rights, 57 Amer. Econ. Rev. Papers and Proc. 347, 354-56 (1967); Hardin, The Tragedy of the Commons, in Economic Foundations of Property Law 2, 4-5 (B. Ackerman ed. 1975).

140 See R. PoSNER, supra note 138, at 30.

111 In part because such a mark is not a scarce resource, one person's use of it does not impose any external costs upon other users. The private costs of use will tend to coincide with the social costs, so that there will be no problem of overutilization. See supra note 139. 
returns from their investments in creating goodwill by making and selling high-quality goods, and so furnishes an incentive to make such investments. Maintaining this incentive requires only that property rights be recognized in some trademarks, not that any particular class of trademarks be protected. ${ }^{142}$ A legal regime, such as that of the common law, that encourages sellers to choose relatively distinctive trademarks, offers this incentive at least as much as a regime that encourages the choice of relatively descriptive marks. It may even offer this incentive to a higher degree, for it makes distinctiveness both easier to achieve and sharper when it is achieved, and the latter enables buyers more efficiently to factor source-related information into their purchasing decisions. It does all this, moreover, without encouraging sellers to withdraw competitively valuable descriptive material from the public domain. The economic approach to property rights does not, therefore, justify the creation of such rights in descriptive marks.

2. Possessory Theories. An alternative basis of property rights, which does not depend upon the scarcity of the monopolized object, asserts that ownership is founded upon possession or occupancy: the first to possess something that was previously unowned becomes its rightful owner, to the exclusion of all others. ${ }^{143}$ This approach, which is arguably the dominant one in the common law, ${ }^{144}$ can plausibly be applied to justify the creation of property rights in descriptive marks through incontestability. It can be said that the registrant, by registering such a mark, keeping it in continuous use for five years, and then filing the statutorily required affidavit, arguably becomes its first possessor, and so deserves to be made its unchallangeable owner.

Closer examination reveals, however, that this argument is flawed. A threshold objection to it is that, so long as the mark has failed to attain distinctiveness, these acts do not amount to actual possession of the registered mark at all, but merely to its intended possession, providing no basis for its ownership. ${ }^{145}$ But a more fun-

142 This was ignored in the majority opinion in Park 'N Fly when it argued that incontestability would be beneficial for the maintenance of these incentives. See $105 \mathrm{~S}$. Ct. at 663 64.

143 See Lafrence Becker, Property Rights: Philosophic Foundations 24-31 (1980).

144 See Epstein, Possession as the Root of Title, $13 \mathrm{GA}$. L. REv. 1221, 1222 (1979); Rose, Possession as the Origin of Property, 52 U. CHI. L. REv. 73, 74-75 (1985). The classic example, familiar to generations of law students, is Pierson v. Post, 3 Cai. R. 175 (N.Y. Sup. Ct. 1805).

${ }_{145}$ Professor Becker argues that only actual occupation, as opposed to intended or declaratory occupation, can be the basis of ownership, for otherwise it would be impossible to limit the scope of the resulting property right: "a foothold in the universe" would be enough 
damental objection, and one that applies even if it is assumed that the registrant is the first possessor, is that the acts of possession prescribed by the statute are purely unilateral, and so cannot justify the creation of exclusive rights that bind the public as a whole. ${ }^{146}$ This objection applies whatever the subject matter of the property rights created, but has particular force in the case of descriptive marks that, but for the operation of incontestability, would be (actively) held in common by the public and not merely (passively) unowned. This means that buyers and sellers alike have so strong an interest in resisting the exclusive appropriation of such marks that the transition from the fact of their possession to the right of property in them cannot be made without a clear demonstration of its justifiability. ${ }^{147}$

An obvious justification would be consent, on the part of the public, to the acquisition of property rights by the possessor. Arguably, in the case of incontestability, the fact that no one opposed a mark's registration, or sought to cancel it before five years had expired, indicates precisely such consent. But this claim ignores the fact that a potential challenger of the registration is confronted by both informational and standing hurdles, ${ }^{148}$ which it will neither wish nor be able to surmount until it becomes a competitor with the registrant, with a strong interest in using the registered mark. By the time this happens, it may be too late to ward off noncancellability and incontestability, especially if (as is likely to be the case) the registrant is selling a novel product or service with an uncertain market. ${ }^{149}$ Therefore, the inference of consent is generally too weak to bind all comers, and to justify the registrant's ownership of the registered mark.

A possible alternative to consent, in many cases, is an economic justification for the link between possession and property rights. It has recently been suggested that only clear and unambig-

to give title to "uninhabited regions of the whole cosmos." See L. BECKER, supra note 143, at 26-28.

146 Professor Epstein regards this as a "perfectly general" objection, which applies to "any and every theory that uses individual actions as the source of entitlements against the collectivity at large." See Epstein, supra note 144, at 1228.

${ }^{147}$ To say that something is "in the public domain" is to express the view that it is, or ought to be, held in common in the sense described here. In such a case, the claims of nonpossessors are particularly strong, and particularly resistant to being overridden by unilateral acts of possession.

${ }^{148}$ See supra notes 86-87 and accompanying text.

149 This is likely to be the case, for the sale of such a product presents one of the occasions on which a seller is particularly likely to use a descriptive mark. See supra notes 53-54 and accompanying text. 
uous acts are treated as constituting the sort of possession that leads to ownership, and it is argued that this insistence reflects the courts' desire to encourage property claimants to remain highly visible. Visibility makes claimants easier to identify and cheaper to transact with, and so helps ensure that the resources in question are directed to their highest-valued uses. ${ }^{150}$ The limitations of this persuasive argument have already been considered, in connection with the substantive discussion of the economic theory; from that discussion, it is apparent that the argument supplies a justification only for the ownership, through possession, of scarce resources which present an allocation problem, and not for property rights in descriptive marks. ${ }^{161}$

Yet another possible alternative rests upon the Lockean labor theory of property. ${ }^{152}$ It could be argued that the registrant is entitled to the ownership of the registered mark because the acts of possession undertaken involve labor, and everybody is entitled to own the fruits of his labor. ${ }^{163}$ There are a number of difficulties, familiar from the literature, ${ }^{154}$ with this approach to property, which are as significant with respect to trademarks as with respect to other kinds of property: Why does one own the products of one's labor? Why, if the labor is viewed as the product of one's body, does one own one's own body? Why, if one expends one's labor upon an object, does one come to own that object instead of losing one's labor? What, if one's labor leads to ownership, are the boundaries of the property right, and why should one not be limited to the value of one's contributions? These are awkward questions, but even if they can be answered satisfactorily, there still remains the root problem: the labor theory fails securely to bridge the gap between possession and property, for to labor upon something is no less unilateral than to take possession of it, and just as incapable of being the source of rights that the whole world is bound to respect. ${ }^{155}$ One way out of this impasse, in the case of

${ }^{230}$ See Rose, supra note 144, at 81-82. Professor Rose does not deal with the objection considered supra at notes 146-47 and accompanying text-that the acts of possession are purely unilateral-or explain how this objection is overridden by considerations of economic efficiency.

131 See supra note 137 and accompanying text.

182 For an account of this theory, see L. Becker, supra note 143, at 32-56.

163 Professor Epstein explores the possibility of using the labor theory to provide a justification for the first possession theory-i.e., to explain how unilateral acts of possession can lead to property rights. See Epstein, supra note 144, at 1225-30. UTOI

${ }^{134}$ See, e.g., L. BEcker, supra note 143, at 37-49; Robert Nozick, ANARchy, State AND

${ }^{18 s}$ See Epstein, supra note 144, at 1228-30. 
incontestability, might be to say that the property right in the descriptive mark is justified by the need to encourage the labor involved in the registrant's acts of adopting such a mark, registering it, and using it. The difficulty with this solution is that it is hard to see why these acts should be thought so valuable as to be worth encouraging at such a high price. It has already been shown that no advantage results from encouraging sellers to choose descriptive marks, for their incentives to produce quality products and thereby garner goodwill are promoted just as effectively-perhaps more effectively-by the adoption of marks that are distinctive from the outset. ${ }^{156}$ And while registration of any mark that is chosen, distinctive or not, is desirable and deserves encouragement, the other incentives to register are arguably strong enough to make it unnecessary to hold out to the registrant the prospect of freedom from validity challenges. ${ }^{157}$

In sum, therefore, the first possession theory, like the economic theory, fails to provide any adequate basis for the withdrawal of descriptive marks from the public domain. Ownership of such marks cannot be justified by the need to maximize the yield from scarce resources, or by the need to provide incentives for useful activity, or upon the ground that there is implicit public consent to the registrant's ownership of such a mark, once the requisite period has elapsed. Nor can it convincingly be said that it is necessary to create a property right in order to protect the expectations of continued exclusive use built up in the registrant. $\mathrm{Ab}$ sent the incontestability provisions, these expectations would either not exist at all, or be much weaker, and in any event, they would be unilateral and not deserving of protection by means that impose a substantial cost upon the public. ${ }^{158}$

\section{A Mechanical Rule?}

A quite different argument can be made that all attempts to evaluate incontestability in terms of theories of property rights are predictably unsatisfactory, for they fail to ask the right question: they treat the incontestability provisions as a rule of positive law that creates property rights, and ask whether this creation is justified, whereas the proper approach is to characterize them as a rule

${ }^{186}$ See supra note 142 and accompanying text.

${ }_{157}$ The most powerful of these other incentives is the fact that registration constitutes constructive notice, and gives the registrant nationwide rights instead of the territorially limited rights available for unregistered marks. See supra note 72.

158 See supra note 131. 
of evidence, and ask whether they can be supported on that basis. On this view, the foundation of property rights in trademarks under the statute continues to be distinctiveness, as it is at common law, and incontestability is simply a new statutory method of proving distinctiveness in certain specified circumstances. ${ }^{150}$ The fact that this method is mechanical, and causes the registered mark automatically and irrebuttably to be treated as distinctive if the specified circumstances exist, is one of its virtues, for this makes it easy and cheap to administer, unlike the common-law rule, which always calls for an expensive investigation into distinctiveness, the outcome of which is uncertain.

This argument is misconceived. Even if incontestability is viewed simply as a rule concerning the proof of distinctiveness, it cannot be supported. There are undoubtedly situations in which a simple and clear rule of decision is desirable, even though the underlying facts are complex and ambiguous, ${ }^{160}$ but the need to decide whether a descriptive trademark has become distinctive is not one of them. A mechanical rule is more liable to produce an erroneous result than one that is flexible and fact-sensitive, and should be used only where it is very likely that any such error would probably be corrected by market transactions. It is sensible, therefore, to decide a title dispute mechanically, for there are generally only two parties involved, who can easily bargain with each other in order to reverse the decision. But an erroneous decision as to distinctiveness is much more difficult to negate. The parties involved in a validity dispute are the claimant of exclusive rights on the one hand, and the public as a whole on the other; in such a situation, it is much less likely that effective bargaining will take place. It is doubtless this recognition that underlies the common law's refusal to decide questions of distinctiveness mechanically.

\section{CONCLUSION}

As the Supreme Court recognized in Park ' $N$ Fly, the incontestability provisions of the Lanham Act permit a seller to monopolize a descriptive trademark. This is a significant departure from the common law, which refused to grant property rights in trademarks unless they were inherently distinctive or had attained distinctiveness by acquiring secondary meaning. The common law

159 I am indebted to Professor Edmund Kitch for this suggestion.

180 Professor Merrill distinguishes between "mechanical" and "judgmental" rules, and argues that the law of adverse possession operates-and rightly so-as a relatively mechanical rule. See Merrill, supra note 127, at 1137-43. 
rule recognized the informational value of trademarks and the disadvantages of allowing the seller to arrogate to itself the informational benefits of natural meanings of words.

The incontestability provisions increase the incentives for sellers to choose descriptive marks for their goods, and to get their chosen marks registered. If they are successful, these provisions place the registrant's competitors at a disadvantage in marketing their similar goods, because once the mark becomes incontestable the competitors can neither use the descriptive term themselves nor challenge its use by the registrant. Moreover, buyers experience greater difficulty and incur higher costs in obtaining the information necessary to make optimal purchasing decisions among similar products. To the extent that the marginal costs of obtaining this information exceed the marginal benefits of doing so, the registrant of the descriptive mark is able to charge monopoly prices for its product. All of this leads to a significant misallocation of resources away from their highest-valued uses. Incontestability under the Lanham Act should therefore be circumscribed so that a seller's right to register, use, or exclude others from using a mark may always be challenged on the ground that the mark is not currently distinctive. 